\title{
Diet, nutrition and the prevention of type 2 diabetes
}

\author{
NP Steyn ${ }^{1, *}$, J Mann ${ }^{2}$, PH Bennett ${ }^{3}$, N Temple ${ }^{4}$, P Zimmet $^{5}$, J Tuomilehto ${ }^{6}$, J Lindström ${ }^{6}$ \\ and A Louheranta ${ }^{7}$ \\ ${ }^{1}$ Chronic Diseases of Lifestyle Unit, Medical Research Council (MRC), Tygerberg, South Africa: ${ }^{2}$ Department of \\ Human Nutrition, University of Otago, Dunedin, New Zealand: ${ }^{3}$ National Institute of Diabetes and Digestive and \\ Kidney Diseases, Phoenix, Arizona, USA: ${ }^{4}$ Centre for Science, Athabasca University, Athabasca, Alberta, Canada: \\ ${ }^{5}$ International Diabetes Institute, Caulfield South, Australia: ${ }^{6}$ National Public Health Institute, Helsinki, Finland: \\ ${ }^{7}$ Department of Clinical Nutrition, University of Kuopio, Kuopio, Finland
}

\begin{abstract}
Objectives: The overall objective of this study was to evaluate and provide evidence and recommendations on current published literature about diet and lifestyle in the prevention of type 2 diabetes.

Design: Epidemiological and experimental studies, focusing on nutritional intervention in the prevention of type 2 diabetes are used to make disease-specific recommendations. Long-term cohort studies are given the most weight as to strength of evidence available.

Setting and subjects: Numerous clinical trials and cohort studies in low, middle and high income countries are evaluated regarding recommendations for dietary prevention of type 2 diabetes. These include, among others, the Finnish Diabetes Prevention Study, US Diabetes Prevention Program, Da Qing Study; Pima Indian Study; Iowa Women's Health Study; and the study of the US Male Physicians.

Results: There is convincing evidence for a decreased risk of diabetes in adults who are physically active and maintain a normal body mass index (BMI) throughout adulthood, and in overweight adults with impaired glucose tolerance who lose weight voluntarily. An increased risk for developing type 2 diabetes is associated with overweight and obesity; abdominal obesity; physical inactivity; and maternal diabetes. It is probable that a high intake of saturated fats and intrauterine growth retardation also contribute to an increased risk, while non-starch polysaccharides are likely to be associated with a decreased risk. From existing evidence it is also possible that omega3 fatty acids, low glycaemic index foods and exclusive breastfeeding may play a protective role, and that total fat intake and trans fatty acids may contribute to the risk. However, insufficient evidence is currently available to provide convincing proof. Conclusions: Based on the strength of available evidence regarding diet and lifestyle in the prevention of type 2 diabetes, it is recommended that a normal weight status in the lower BMI range (BMI 21-23) and regular physical activity be maintained throughout adulthood; abdominal obesity be prevented; and saturated fat intake be less than $7 \%$ of the total energy intake.
\end{abstract}

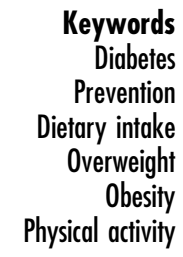

Type 2 diabetes, formerly known as non-insulin-dependent diabetes (NIDDM), accounts for most cases of diabetes mellitus worldwide. It is estimated that in 2000 there were approximately 150 million individuals with the disease and that this number is likely to double by $2025^{1}$. Type 2 diabetes is the fourth or fifth leading cause of death in most developed countries and there is growing evidence that it has reached epidemic proportions in many developing and newly industrialised countries ${ }^{2}$. The lowest rates of type 2 diabetes are found in rural communities where people retain traditional lifestyles ${ }^{2}$.

Dramatic changes in the prevalence or incidence of type 2 diabetes have been observed in communities where there have been major changes in the type of diet consumed, from a traditional indigenous diet to a typical 'Western' diet, e.g. Pima Indians in Arizona, Micronesians in Nauru and Aborigines in Australia ${ }^{3-5}$. Changing disease rates are almost certainly explained by changes in several dietary factors as well as by changes in other lifestyle related factors, notably a reduction in physical activity.

\section{Classification and diagnosis}

As undiagnosed diabetes represents an important fraction of the population with the disease, most epidemiological studies are undertaken by testing all subjects in the population of interest. Without systematic testing an incomplete and potentially misleading picture of the frequency or distribution of the disease is obtained. 
Furthermore, because of the differences in criteria, comparisons of rates between recent and earlier studies should be made with caution.

The 1985 internationally accepted World Health Organisation (WHO) criteria for the diagnosis and classification of diabetes led to much greater uniformity of methods used in epidemiological studies ${ }^{6}$. Recently, the diagnostic criteria have been revised, first by the American Diabetes Association ${ }^{7}$ and then by the $\mathrm{WHO}^{8}$, thus complicating comparisons of studies that are analysed according to the new criteria and those with the earlier WHO criteria.

The revised diagnostic criteria accord greater importance to the fasting plasma glucose (FPG) concentration as a criterion for diagnosis. The FPG value considered diagnostic of diabetes has been lowered to $\geq 126 \mathrm{mg} / \mathrm{dL}$ $(\geq 7.0 \mathrm{mmol} / \mathrm{L})^{7,8}$ from the former value of $140 \mathrm{mg} / \mathrm{dL}$ $(7.8 \mathrm{mmol} / \mathrm{L})$ and over. The category of impaired glucose tolerance (IGT) was retained at 2 -hr post-load glucose levels from $140 \mathrm{mg} / \mathrm{dL}(7.8 \mathrm{mmol} / \mathrm{L})$ to less than $200 \mathrm{mg} / \mathrm{dL}$ $(11.1 \mathrm{mmol} / \mathrm{L})$. An additional category, impaired fasting glycaemia (IFG), was introduced to categorise individuals who have FPG levels that are above normal but fall short of the new diagnostic FPG level for diabetes, i.e. FPG $110 \mathrm{mg} / \mathrm{dL}(6.1 \mathrm{mmol} / \mathrm{L})$ to $125 \mathrm{mg} / \mathrm{dL}(<7.0 \mathrm{mmol} / \mathrm{L})$. It is now apparent that only a minority of individuals with IGT have IFG, and conversely, only a minority of those with IFG have IGT ${ }^{9,10}$.

The change in diagnostic criteria has resulted in some individuals being reclassified as having diabetes, i.e. individuals with FPG from $126 \mathrm{mg}$ to $139 \mathrm{mg} / \mathrm{dL}$ and with post-load 2-hr glucose values of $<200 \mathrm{mg} / \mathrm{dL}$, thereby resulting in an increase in prevalence ${ }^{9}$. Furthermore, some recent papers have reported the prevalence of diabetes based solely on fasting glucose values, thereby ignoring individuals with abnormal 2-hr values based on oral glucose tolerance testing. Such a strategy leads to rates that are appreciably lower than in studies where glucose tolerance tests are done.

\section{Epidemiology}

\section{Prevalence and incidence of type 2 diabetes}

In recent decades, dramatic increases in the prevalence and incidence of type 2 diabetes have occurred in many parts of the world especially in the newly industrialised and developing countries ${ }^{11}$ (Fig. 1). Indeed, the majority of cases of type 2 diabetes in the future will occur in developing countries with India and China having more cases than any other country in the world ${ }^{1}$.

In the United States, the most complete information on the prevalence of type 2 diabetes has been obtained from the US National Health Examination Surveys ${ }^{12,13}$. Surveys carried out in adults aged 20-74 years in representative samples of the US population show that the prevalence differs considerably in different ethnic groups ${ }^{13,14}$ (Fig. 1).

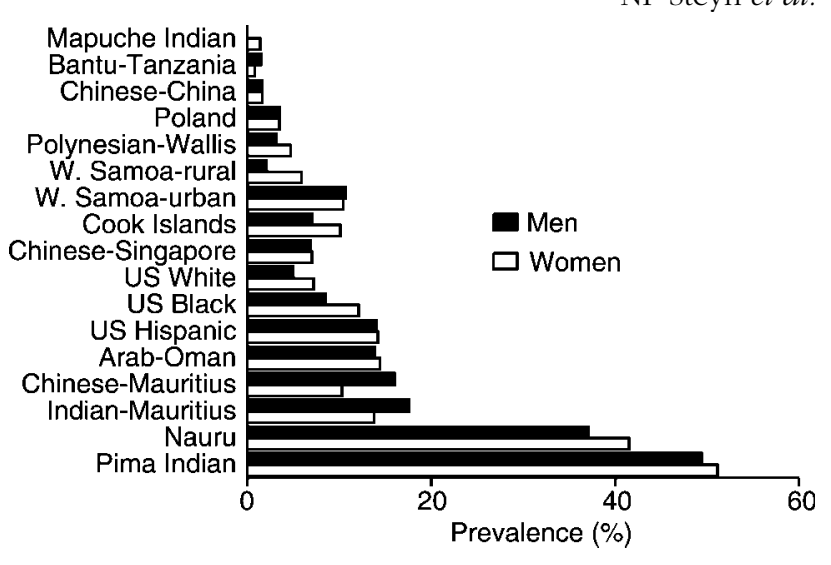

Fig. 1 Prevalence of diabetes according to $1980 \mathrm{WHO}$ criteria in men and women aged 30-64 years in different countries and various ethnic groups (adapted from King and Rewers ${ }^{11}$ )

The prevalence in Hispanic Americans, particularly Mexican Americans, is higher than in the white or black populations and African Americans have greater prevalence than whites ${ }^{15}$. Native American populations have prevalence rates of type 2 diabetes which are even higher than those of Hispanic and African Americans, although the prevalence does vary from one native American group to another ${ }^{16,17}$.

Data from the health examination surveys (NHANES III) conducted between 1988 and 1994 showed that 5.1\% of US adults aged 20 years and older had previously diagnosed diabetes ${ }^{12}$. The prevalence of undiagnosed diabetes, based only on FPG levels of $\geq 126 \mathrm{mg} / \mathrm{dL}$, was $2.7 \%$, whereas with glucose tolerance tests and using the 1985 WHO criteria was $6.3 \%{ }^{9}$. The total prevalence was $7.8 \%$ based on diagnosed diabetes and FPG levels only, or $11.4 \%$ when based on the 1985 WHO criteria, rates appreciably higher than seen in earlier surveys. Among persons aged 40-74 years the prevalence (based on the fasting criteria) had increased from $8.9 \%$ in 1976-1980 to $12.3 \%$ in 1980-1994-a 38\% increase over the course of a decade ${ }^{12}$. Data from the Behavioural Risk Factor Surveys, carried out on representative samples of US adults, 18 years and older, indicated an increase of diagnosed diabetes between 1991 and 1999 from 4.1 to $6.0 \%$ in men, and from 5.6 to $7.6 \%$ in women, an increase of approximately $40 \%$ in less than a decade ${ }^{18,19}$.

Turning to the situation in developing populations, in African Sub-Saharan countries, formerly, the disease either was absent, or was very low in occurrence. Even as late as 1987 , in a rural village in Togo, West Africa, none of a large series of subjects examined had diabetes ${ }^{20}$. In South Africa, formerly, the disease was rare in rural areas ${ }^{21}$, moreover, even in urban centres the proportion affected was low, $1.1 \%^{22}$. However, in strong contrast, in present day city populations, as in Durban in 1993, the crude incidence rate in Africans is actually higher than that in the local white population, namely 6.7 versus $4.5 \%{ }^{23}$. 
Increases in type 2 diabetes have been observed in many other populations in the past half-century. For example, among the Pima Indians a $40 \%$ increase in the prevalence occurred between 1967 and 1977, primarily due to an increase in the incidence (the rate of development in new cases) of the disease ${ }^{17}$.

Incidence studies using standardised glucose tolerance tests have been performed in the Pima Indians of Arizona $^{24,25}$ and among Micronesians in the central Pacific island of Nauru ${ }^{26}$, populations with very high incidence rates. Among Pima Indians, the age-specific incidence and aged-adjusted incidence rates of diabetes have increased over the course of two decades ${ }^{25,27}$ whereas in Nauru, the incidence may now be falling.

\section{Mortality}

Type 2 diabetes is associated with excess mortality mainly attributable to the vascular complications of the disease. In Caucasian populations, much of the excess is attributable to cardiovascular disease, especially ischaemic heart disease ${ }^{28-30}$, but in others such as Asian and American Indian populations renal disease contributes to a considerable extent ${ }^{31,32}$. In some developing nations, an important component of the excess is due to infections ${ }^{33}$.

Age-adjusted mortality rates among persons with diabetes are 1.5-2.5 times higher than in the general population $^{28,30}$ but the excess is greater in younger age groups and diminishes at older ages. The excess mortality leads to a decreased life expectancy among those with type 2 diabetes ${ }^{32,34}$. The extent of the reduction of life expectancy is dependent on the age of onset of the disease, but averages approximately 10 years in countries such as the United States. Mortality in women is generally lower than in men, but the relative risk of death in women with diabetes is increased so that the absolute rates approach those seen in men with type 2 diabetes ${ }^{35,36}$.

Increased mortality in patients with type 2 diabetes is seen mainly among those with complications. Risk factors include proteinuria and retinal disease, and the classical risk factors for heart disease. Hyperlipidaemia, hypertension and smoking each contribute disproportionately to death rates among those with type 2 diabetes ${ }^{37}$. Mortality rates also increase with increasing duration of the disease $\mathrm{e}^{30,32}$.

\section{Metabolic changes during development of type 2 diabetes: insulin resistance and impaired glucose homeostasis}

Resistance to the action of insulin is the underlying abnormality in most people who develop type 2 diabetes $^{38,39}$ (Fig. 2). Insulin resistance results from an interaction between genetic and environmental factors. The genetic factors are not clearly understood and it is also uncertain whether some environmental factors are more important than others. A wide range of lifestyle related

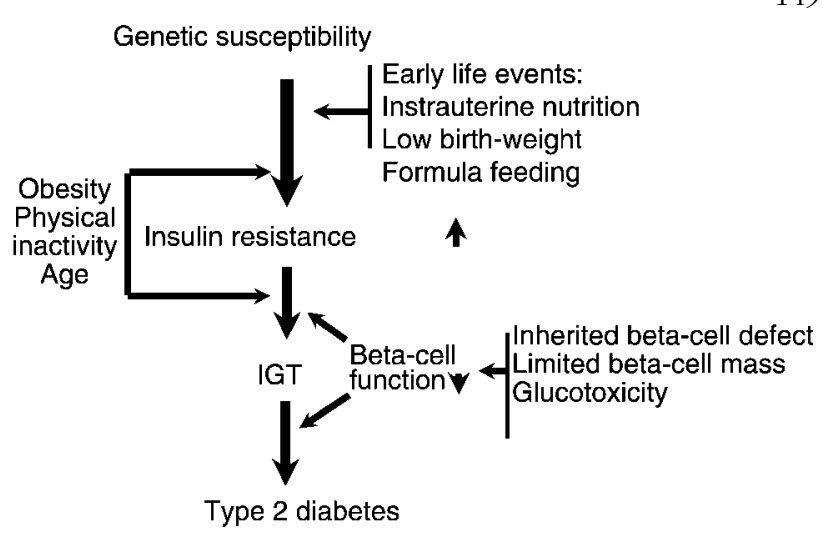

Fig. 2 Stages and risk factors in the development of type 2 diabetes

factors has been implicated, ranging from early life events to physical inactivity, several dietary attributes and subsequent development of overweight and obesity. These factors may be associated both with the development of insulin resistance as well as with progression from insulin resistance to states of impaired glucose metabolism (IFG, IGT) and eventually type 2 diabetes. The initial reaction of the $\beta$ cells is to increase output of insulin in order to overcome the insulin resistance and so to maintain normal blood glucose levels.

Fasting insulin concentrations in subjects with normal glucose tolerance represent a surrogate marker of insulin resistance and numerous longitudinal studies have shown that higher fasting insulin levels (or other indices of insulin resistance) predict the development of type 2 diabetes. Unless insulin resistance is reversed, hypersecretion of insulin is usually insufficient to maintain normoglycaemia indefinitely and progression to IGT and IFG follows ${ }^{39-42}$. These early abnormalities of glucose metabolism usually, progress further to type 2 diabetes ${ }^{43,44}$. While raised levels of insulin are invariably associated with insulin resistance, the insulin secretion declines at a variable rate as the disease progresses through IGT to type 2 diabetes. This occurs either because of an inherent defect of the $\beta$ cell or because of glucotoxicity, whereby the $\beta$ cell is damaged as blood glucose levels rise ${ }^{45}$. The extent to which this sequence of events can be halted or reversed is considered in Section 8.

IGT or type 2 diabetes often coexist with other clinical and metabolic abnormalities which are associated with insulin resistance and central obesity. Hypertension, raised levels of triglyceride, reduced levels of high density lipoprotein, hyperuricaemia and raised levels of plasminogen activator inhibitor- 1 are some of the constellation of features which along with hyperglycaemia of varying severity constitute the 'syndrome' now known as the metabolic syndrome or insulin resistance syndrome ${ }^{46-50}$. These features all contribute to the increased risk of cardiovascular disease associated with IGT and type 2 diabetes and may coexist together with hyperinsulinaemia before abnormalities of blood glucose are detectable. 


\section{Irreversible risk factors}

The following section deals with important risk factors for the development of type 2 diabetes, which are based on inherent genetic or developmental factors, which are not modifiable by dietary and/or other lifestyle changes.

\section{Race/etbnicity}

The prevalence of type 2 varies considerably among populations of different ethnic origins living in apparently similar environments ${ }^{11}$. For example, in Singapore the frequency of diabetes in 1992 was $8.5-7.7 \%$ in Chinese men and women aged 18-69 compared with 13.3 and $12.3 \%$, respectively, among the Asian Indians and Malays $^{51}$. High prevalence rates of diabetes have also been found among Asian Indians compared with the indigenous populations in the United Kingdom, Fiji, South Africa and in the Caribbean ${ }^{52-54}$. Considerable differences in the prevalence of diabetes have also been described among the multi-ethnic populations of Hawaii and New Zealand, where the Native Hawaiians and Maori populations, both of Polynesian origin, have higher prevalences than other ethnic groups ${ }^{55,56}$. While environmental factors undoubtedly account for some of these differences, they are likely also to reflect inherent ethnic differences in susceptibility to the disease.

\section{Familial aggregation}

The empirical risk of having type 2 diabetes is increased 2 to 6-fold if a parent or sibling has the disease ${ }^{57}$. Consequently, a positive family history is a practical, albeit a crude way, of estimating if an individual is likely to have inherited susceptibility to the disease. On the other hand, familial aggregation may occur for non-genetic reasons. Family members often share a similar environment, particularly as children and in adolescence, thus familial aggregation alone is not definitive evidence of genetic determinants. Furthermore, with a disease as frequent as type 2 diabetes two or more family members may well have the disease by chance alone.

\section{Genetic factors}

A higher degree of concordance for type 2 diabetes in identical twins than in dizygotic twins provides strong evidence that genetic factors are important in determining susceptibility $^{58,59}$. However, the fact that not all monozygotic twins are concordant for the disease confirms the importance of environmental factors.

Further evidence of the importance of genetic factors as predisposing factors for type 2 diabetes comes from studies of admixed populations. Differences in prevalence among persons of mixed racial background from that in parent populations with notably different prevalence of the disease are indicative of the importance of genetic determinants. Such relationships have been described among Nauruans and Pima Indians where full-heritage members of these groups have significantly higher rates of diabetes than those of mixed heritage $e^{60,61}$. Similarly, among the Mexican American population of San Antonio, the prevalence of type 2 diabetes is related to the degree of American Indian admixture, with higher rates associated with greater proportions of American Indian genes ${ }^{62}$.

Much research activity has centred on attempts to unravel the genes, which confer susceptibility to type 2 diabetes, a number of genes are likely to be involved. At present, it is impossible to quantify the relative contributions of genetic and environmental factors.

\section{Age and gender}

The prevalence and incidence of type 2 diabetes vary to some extent between the sexes from one population to another, but these differences are relatively small and appear to be accounted for by differences in other risk factors such as obesity and physical activity.

The prevalence of type 2 diabetes increases with age although the patterns of incidence vary considerably. In high incidence populations, the prevalence may increase markedly in the younger adult years (e.g. 20-35 years of age), whereas in others the incidence and prevalence increase mainly in older individuals (e.g. 55-74 years of age). In most populations, a decrease in prevalence is seen in the oldest age groups (e.g. 75+ years) because of higher mortality rates in those with the disease.

Type 2 diabetes in relatively affluent societies usually develops in the middle to older age groups. In developing countries, however, because of the younger age distribution of the population, many cases occur in young and middle aged adults. In Caucasian populations in the United States and Europe, the prevalence of type 2 diabetes increases with age at least into the seventies ${ }^{63}$.

Type 2 diabetes was formerly considered as a disease of adults. In recent years, however, there have been many reports of its occurrence in childhood and adolescence ${ }^{64-66}$. As in adults, the disease in children is frequently asymptomatic and is detected mainly by screening. In Japan, a national programme for screening school children has been in place since 1992 and the numbers recognised to have type 2 diabetes have increased progressively so that the prevalence and incidence of type 2 diabetes greatly exceed those of type 1 diabetes ${ }^{67}$. In American Indian children and adolescents, type 2 diabetes was first described among the Pima Indians ${ }^{68}$ and the prevalence has increased steadily over the past 30 years $^{64}$. Reports of type 2 diabetes in this age group have appeared from many ethnic groups in recent years including other Native American tribes, Mexican Americans, African Americans, Chinese, Polynesians, Asian Indians and Arabs from the Gulf States. It appears that among Caucasians, type 2 diabetes is still seen relatively infrequently in children and young adults. 


\section{Modifiable risk factors}

This section comprises a review on risk factors related to dietary and other lifestyle factors. These factors have been shown to have an increased or a decreased risk for the development of type 2 diabetes and can be modified by lifestyle changes.

\section{Obesity}

Obesity is a frequent concomitant of type 2 diabetes, and in many longitudinal studies has been shown to be a powerful predictor of its development ${ }^{25,69}$. Obesity has increased rapidly in many populations in recent years ${ }^{70-72}$ because of an interaction between genetic and environmental factors. These include: metabolic characteristics $^{73-75}$; physical inactivity ${ }^{74,76-78}$; habitual energy intake in relation to expenditure ${ }^{76}$; and macronutrient composition of the diet ${ }^{78-84}$.

This increase in obesity has been accompanied by an increasing prevalence of type 2 diabetes ${ }^{19}$. Since obesity is such a strong predictor of diabetes incidence, it appears that the rapid increases in the prevalence of type 2 diabetes seen in many populations in recent decades are almost certainly related to increasing obesity. Data from the Nurses' Health Study suggest that the lowest risk of diabetes occurs in individuals who have a body mass index $(\mathrm{BMI})<21$, with increasing prevalence seen as obesity levels increase ${ }^{69}$.

Only a limited number of studies have measured age and sex specific incidence rates for type 2 diabetes in relation to obesity. Such rates vary considerably according to other risk factors. There are large differences in agespecific incidence rates according to BMI in the Pima Indians ${ }^{25}$. Those with higher BMI have much higher incidence rates of type 2 diabetes at earlier ages than those with lower BMI among whom the incidence rises in the older age groups. In non-obese individuals, the incidence of type 2 diabetes is low even in populations such as the Pima Indians where the overall risk of the disease is very high. The relationship of incidence of type 2 diabetes to obesity also varies with other risk factors. For example, in the Pima Indians the incidence rises much more steeply with BMI in those whose parents have diabetes than in these who do not. This relationship indicates an interaction between risk factors.

Several studies indicate that waist circumference or waist-to-hip ratio may be a better indicator of the risk of developing diabetes than $\mathrm{BMI}^{85-87}$. Such data suggest that the distribution of body fat is an important determinant of risk as these measures reflect abdominal or visceral obesity. In Japanese American men, for example, the intra-abdominal fat, as measured from CAT scans, was the best anthropometric predictor of diabetes incidence ${ }^{86}$

Given the importance of central adiposity as a determinant of diabetes risk it is necessary to consider whether the usually quoted 'normal range' for BMI $\left(18.5-24.9 \mathrm{~kg} / \mathrm{m}^{2}\right)$ is appropriate for all populations. It might be appropriate to also suggest an appropriate range for some measure of the distribution of body fat (e.g. waist circumference, waist/hip ratio). The Nurses Health Study suggests that for populations of European descent risk of type 2 diabetes increases even within the normal BMI range and that a BMI of $21 \mathrm{~kg} / \mathrm{m}^{2}$ might be an optimum level $^{69}$. However, for a given BMI, several (perhaps all) populations of Asian descent appear to have an appreciably greater proportion of body fat than that of Europeans. It seems conceivable, therefore, that a lower BMI might be desirable ${ }^{88}$. In the absence of definitive data from prospective studies in these countries, at present it may be appropriate to similarly suggest an optimum level towards the lower end of the normal range. On the other hand, people of Pacific descent (Polynesians) have a relatively high proportion of lean body mass compared with Europeans for any given BMI. Therefore, a higher BMI cut off may be acceptable. However, the particularly high risk of type 2 diabetes and other co-morbidities of obesity in these populations may negate this apparently beneficial anthropometric attribute. Again, in the absence of appropriate prospective studies, it may be wise to suggest that their BMI should not exceed the conventional normal range. Because there are fewer data available concerning waist circumference or waist/hip ratio in different populations, it is appropriate to continue to use the WHO recommended BMI range $\left(18.5-24.9 \mathrm{~kg} / \mathrm{m}^{2}\right)$ and population mean of $21 \mathrm{~kg} / \mathrm{m}^{288}$.

\section{Physical inactivity}

Numerous studies have indicated the importance of physical inactivity in the development of type 2 diabetes ${ }^{89-92}$. Indeed, in most studies its relative importance may be underestimated because of imprecision in measurement. In the Nurses' Health Study, women who reported exercising vigorously had an age-adjusted incidence rate of self-reported clinically diagnosed diabetes that was two-thirds as high as that of women who exercised less frequently ${ }^{89}$. The deleterious effect of low levels of physical activity is seen particularly among those subjects who have other risk factors such as high BMI, hypertension or parental diabetes. Similarly, among male physicians, the incidence of self reported diabetes was negatively related to the frequency of vigorous exercise and the strength of this relationship was greater in those with higher $\mathrm{BMI}^{90}$. For equivalent degrees of obesity, more physically active subjects have a lower incidence of the disease ${ }^{92}$.

Recommendations with regard to physical activity as a preventative measure for developing type 2 diabetes are still difficult to quantify. Currently, guidelines propose moderate physical activity on at least 5 days per week and do not specify heart rate targets However, more recent evidence suggests that vigorous exercise is required to improve insulin sensitivity ${ }^{93}$. A study by McAuley et al. ${ }^{93}$ 
showed that insulin sensitivity improved in normoglycaemic insulin-resistant adults who undertook vigorous exercise and not in those who complied with current moderate exercise programmes. The vigorous exercise programme required participants to train five times a week for at least $20 \mathrm{~min}$ per session at an intensity of $80-90 \%$ of age-predicted maximum heart rate ${ }^{93}$.

\section{Fat: quantity and quality}

Both the amount and quality of dietary fat may modify glucose tolerance and insulin sensitivity ${ }^{94-96}$. A high fat content in the diet may result in deterioration of glucose tolerance by several mechanisms including decreased binding of insulin to its receptors, impaired glucose transport, reduced proportion of glycogen synthase and accumulation of stored triglycerides in skeletal muscle ${ }^{97-101}$. The fatty acid composition of the diet, in turn, affects tissue phospholipid composition, which may relate to insulin action by altering membrane fluidity and insulin signalling ${ }^{94}$.

\section{Amount offat consumed}

In experimental animals, all high-fat diets (with the exception of $n-3$ fatty acids) have been shown to result in insulin resistance relative to high carbohydrate diets $94,99,100,102,103$. The data from epidemiological and human intervention studies are less consistent. In two crosssectional studies, total fat intake was higher in glucose intolerant and type 2 diabetic subjects ${ }^{104}$ and in subjects with recurrent gestational diabetes mellitus ${ }^{105}$ compared with normoglycaemic controls. Furthermore, a high fat intake has been shown to predict development of IGT in a group of healthy subjects ${ }^{106}$ and progression from IGT to type 2 diabetes in a group of subjects with $\mathrm{IGT}^{107}$. High total fat intake has also been associated with higher fasting insulin concentrations ${ }^{108,109}$ and a lower insulin sensitivity index ${ }^{110}$. On the other hand, there are several studies, which show no association between diabetes risk and total fat intake ${ }^{111-119}$. Few human intervention studies have examined the effects of high fat, low carbohydrate diets on diabetes risk, and the results have been inconsistent ${ }^{120-127}$.

\section{Nature of dietary fat}

As previously mentioned, in animal experiments saturated, monounsaturated and polyunsaturated fats, excluding $n-3$ fatty acids, have caused insulin resistance when fed as high-fat diets ${ }^{94,99,100,102,103}$. In epidemiological studies, a high saturated fat intake has been associated with higher risk of IGT $^{106,128}$ and higher fasting glucose ${ }^{129,130}$ and insulin levels ${ }^{108,131}$. Higher proportions of saturated fatty acids in serum lipids/muscle phospholipids have been associated with higher fasting insulin levels ${ }^{132}$, lower insulin sensitivity ${ }^{133}$ and higher risk of developing type 2 diabetes $^{134}$. Higher vegetable fat (unsaturated fat) and PUFA intake have in turn been associated with a lower risk of type 2 diabetes $^{115,118,119}$, as well as lower fasting and 2-hr glucose concentrations ${ }^{130,135}$. Furthermore, higher proportions of long-chain polyunsaturated fatty acids in skeletal muscle phospholipids have been associated with better insulin sensitivity in humans ${ }^{136,137}$. With respect to monounsaturated fatty acids, the epidemiological data are inconsistent. Some studies indicate that a high intake of monounsaturated fatty acids may be detrimental in terms of increasing diabetes risk ${ }^{106,138}$. However, it should be noted that in a typical 'Western' diet the monounsaturated fatty acids are not derived from vegetable oils but to a large extent coexist with saturated fat in sources such as meat and milk products. Therefore, the detrimental effects reported $^{106,138}$ may be due to the effects of saturated fatty acids in these food sources ${ }^{106}$.

In two short-term human intervention studies, replacement of a considerable portion of saturated fat by unsaturated fat improved glucose tolerance in young healthy women ${ }^{139}$ and in middle-aged glucose-intolerant hyperlipidaemic subjects ${ }^{140}$. A longer-term study by Vessby et $a l .{ }^{141}$ confirmed that a substitution of monounsaturated fat for saturated fat significantly improved insulin sensitivity in healthy subjects after a 3-month dietary period. An interesting interaction between total fat intake and fatty acid composition of dietary fat was reported: the favourable effect of substituting monounsaturated fat for saturated fat was lost in individuals consuming more than $37 \%$ of energy as $\mathrm{fat}^{141}$. There are only a few studies in which the effects of single fatty acids on glucose and insulin metabolism have been examined. In two short-term studies with single saturated fatty acids-lauric, palmitic and stearic acids-no effect on glucose and insulin metabolism was found when these saturated fatty acids were compared with an equivalent energy exchange with monoenes ${ }^{142,143}$.

In the light of present knowledge regarding the relationships between type 2 diabetes and nature and quantity of dietary fat, as well as the absence of definitive data regarding precise percentage of fat to total energy, it seems reasonable to suggest that quantitative recommendations should follow those suggested for reduction of cardiovascular risk.

\section{The role of trans fatty acids}

Data on the effects of trans fatty acids on glucose metabolism are sparse. A report from the Nurses Health Study ${ }^{118}$ suggests a positive association between trans fatty acid intake and risk of type 2 diabetes. In mouse islet cells trans fatty acids potentiate insulin secretion compared with cis-isomers $^{144}$. Two human experiments have been reported. In patients with type 2 diabetes, a 6-week diet high in trans fatty acids (20\% of energy) increased postprandial c-peptide and insulin responses compared with a diet high in cis-monounsaturated fatty acids ${ }^{145}$. In healthy young women, consumption of a 4-week diet with $5 \%$ of energy from trans fatty acids did not change insulin sensitivity compared to an oleic acid enriched diet ${ }^{146}$. 


\section{The role of $n$-3 fatty acids}

In rodent studies, $n-3$ fatty acids ameliorate insulin resistance induced by high-fat feeding $95,100,103$. In some epidemiological studies, an inverse association between fish intake and risk of IGT has been observed ${ }^{106,114}$. Most intervention studies aimed at investigating the effect of fish oil on insulin sensitivity have been done in patients with type 2 diabetes and have been negative ${ }^{147-151}$. A negative result has, however, also been reported in healthy subjects $^{141}$.

\section{Carbohydrates: quantity and quality}

\section{Total carbobydrates}

As mentioned earlier, some controversy surrounds the optimal ratio of carbohydrate-to-fat in the diet with respect to the prevention of chronic diseases, including type 2 diabetes. The main question is whether high intakes of either carbohydrate or fat are deleterious over time and will predispose individuals to diabetes ${ }^{152}$.

Due to a paucity of controlled trials on which to base recommendations for macronutrients we have to rely on the available evidence from epidemiological studies. Causal inferences thus need to be made with the recognition that the probability of confounding variables may exist in the different populations ${ }^{73}$. There are marked differences in various countries of the world with respect to the fat-to-carbohydrate ratios consumed by different populations ${ }^{153}$. A significant positive association has been shown between dietary fat consumption and the proportion of the population who are overweight. This supports the notion of a reduced fat (increased carbohydrate) intake as a preventative measure for chronic diseases ${ }^{154}$. There is some evidence that a high carbohydrate intake decreases the prevalence of diabetes ${ }^{104,155}$. However, numerous studies have reported that an increased intake of carbohydrates can reduce HDL levels and raise fasting plasma triacylglycerol concentrations ${ }^{156-}$ 160. These are mainly short-term, isocalortic, metabolic studies rather than long-term ad lib studies where weight is allowed to decrease on the lower fat content diets.

Two cohort studies ${ }^{116,117-161}$ and a recent review ${ }^{162}$ did not find an association between total carbohydrate and diabetes risk. It is known that a high carbohydrate intake increases the requirement for insulin secretion in order to maintain glucose homeostasis ${ }^{163}$. Insulin secretion by beta-cells is glucose sensitive and a high intake of carbohydrate in relation to energy intake, produces higher post-prandial insulin levels. It is possible that repeated stimulation of a high insulin output by a high carbohydrate diet could speed up an age-related decline in insulin secretion and lead to an earlier onset of type 2 diabetes ${ }^{152,164}$. The quality as well as the quantity of carbohydrate may hasten this response ${ }^{152}$. The most recent American dietary guidelines recommend intake of a variety of grain products (including whole grains) equating to six or more servings a day ${ }^{165}$. The FAO/WHO recommend that carbohydrate in the diet should comprise at least $55 \%$ of total energy intake in 'normal' healthy individuals ${ }^{166}$. There is, however, no specific carbohydrate guideline, which is aimed at the prevention of type 2 diabetes. Therefore, a wide range of carbohydrate intakes may be acceptable in terms of achieving a low risk of type 2 diabetes with type and source of carbohydrate being more important than quantity.

\section{Dietary fibre and the glycaemic index}

Dietary fibre in this context is composed of non-starch polysaccharides (NSPs), plus lignin, oligosaccharides and resistant starch. Resistant starch is that portion of starch that resists digestion, passes into the lower intestine, and ferments there. Dietary fibre found in foods consists of cellulose, hemicelluloses, pectins, hydrocolloids, resistant starches and resistant oligosaccharides ${ }^{166}$. Dietary fibre is one of the factors that influences post-prandial glucose and insulin responses. Other factors include the macronutrient composition of meals, processing, cooking and other characteristics of the carbohydrates ${ }^{167-170}$. Since there are considerable differences in the physiological responses to different forms of carbohydrate, the term glycaemic index (GI) was coined in $1981^{171}$. It is defined as the glycaemic response elicited by a $50 \mathrm{~g}$ carbohydrate portion of a food expressed as a percentage of that elicited by a $50 \mathrm{~g}$ portion of a reference food (glucose or white bread). GI is a measure of the post-prandial glucose response after carbohydrate consumption. Low GI foods have lower 2-hr areas under the glucose curve than the reference food, while high GI foods have higher areas.

The effects of the various components of dietary fibre have been implicated in the prevention and management of a range of diseases, including type 2 diabetes, as early as the seventies ${ }^{172,173}$. Cross-sectional studies suggest that lack of dietary fibre may be a causative factor in type 2 diabetes and have shown an inverse relationship between fibre intake and blood insulin levels ${ }^{110,174}$; implying that fibre improves insulin sensitivity. Three large cohort studies, the Health Professionals Follow-up study carried out on men aged $40-75^{117}$, the Nurses Study carried out on women aged $40-65^{116}$, and the Iowa Women's Health Study carried out on women aged 55-69 years ${ }^{161}$ have studied the effects of fibre and glycaemic load on risk of developing diabetes. All three studies clearly showed that a relatively low intake of dietary fibre significantly increased the risk of type 2 diabetes. The association was found to be strong for cereal fibre, a rich source of insoluble fibre, but much weaker for sources of soluble fibre ${ }^{117-161,175,176}$. The protective association in the extreme quintiles revealed a risk ratio of 0.64-0.72, after correcting for related variables such as age, BMI, smoking and physical activity. Two of the studies reported that glycaemic load is associated with risk of diabetes ${ }^{116,117}$. They showed an increased relative the risk of type 2 
diabetes of 2.2 in women and 2.1 in men, with a combination of low cereal fibre intake and a high glycaemic load. However, the third cohort study did not detect a risk associated with $\mathrm{GI}^{117}$. Studies carried out in people with diabetes shed further light on the possible roles of dietary fibre and GI. Many studies have shown that glycaemic control is improved and the total LDL cholesterol reduced on relatively high carbohydrate, low fat diets including naturally occurring fibre-rich foods compared with relatively low carbohydrate, higher fat diets. A similar benefit has also been shown when comparing diets with similar carbohydrate:fat ratios, but with the experimental diet being appreciably higher in fibre. Feeding supplements of dietary fibre for several weeks has also been shown to lower both post-prandial glycaemia, insulin levels ${ }^{177-179}$ and an overall improvement in glycaemic control as measured by $\mathrm{HbA}_{1}$. This is seen both in normal subjects and in those with type 2 diabetes. Of considerable interest is the fact that in the dietary intervention studies, soluble forms of dietary fibre, regardless of whether it was taken as a supplement or in food, had an appreciably greater beneficial effect than was the case for insoluble, largely cereal derived forms of dietary fibre. Numerous studies have illustrated beneficial effects of a diet comprising foods with a low GI in type 2 diabetics ${ }^{180-183}$. Furthermore, some studies have found that foods with a high GI increase fasting triacylglycerol concentrations, even when the amount of carbohydrate is kept constant ${ }^{184,185}$.

Recently, investigators have also considered the possibility that factors other than fibre that are contained in cereals and legumes may influence the risk for chronic diseases $^{186}$. Some of these include micronutrients such as selenium and vitamin E, antioxidants, phytochemicals, isoflavins and lignans. Since many of these factors occur together in cereals it is difficult to determine the precise benefits of each. While the benefits of the 'whole' grains have been demonstrated to reduce risk of CHD in women in the Nurses Health Study ${ }^{187}$ and in the Iowa Women's Health Study ${ }^{188}$, the effects of whole grains on the reduction of type 2 diabetes risk remains to be explored.

In general dietary recommendations, the recommended fibre intake in terms of NSPs has been set at an average intake of $18 \mathrm{~g}$ (range $12-24 \mathrm{~g}$ ) of NSP per day for adults in the $\mathrm{UK}^{189}$ and at $25 \mathrm{~g}$ fibre in the USA ${ }^{165}$. Good sources of NSPs ( $>4 \mathrm{~g}$ per portion) are: legumes, pulses, brussels sprouts, whole wheat bread, rye bread, wholemeal pasta, bran cereals and wholegrain cereals ${ }^{190}$. However, the wide range of studies quoted here suggest that an appreciably larger quantity is required to reduce the risk of diabetes or improve glycaemic control in those with the disease. Since there is no clear indication regarding the precise quantity of dietary fibre to protect against diabetes, or which type of dietary fibre confers the greatest benefit, it may be most appropriate to emphasise appropriate carbohydrate sources rather than to specify precise quantities.

\section{Micronutrients}

\section{Vitamin $E$}

Studies in patients with type 1 diabetes have revealed an increased level of oxidative stress ${ }^{191}$ and evidence that vitamin $\mathrm{E}$ may help prevent this ${ }^{192}$. However, little is known concerning the relationship between vitamin $\mathrm{E}$ intake and the development of type 2 diabetes.

Two cohort studies conducted in Finland examined the relationship between the blood level of vitamin $\mathrm{E}$ and the risk of type 2 diabetes ${ }^{193,194}$. One study reported that a low plasma level of this anti-oxidant vitamin is associated with a 3.9-fold elevated risk of developing the disease ${ }^{193}$. The association was independent of various possible confounding factors. A nested case-control study carried out within a cohort study reported that subjects with a high serum vitamin E level had a 39\% lower risk of diabetes compared to those with a low level of vitamin $\mathrm{E}^{194}$. However, in contrast to the previous study ${ }^{193}$ this association disappeared when the risk ratio was adjusted for various coronary heart disease risk factors. This suggests that a high level of vitamin E may be merely a marker for a healthy lifestyle.

While the relationship between vitamin $\mathrm{E}$ and the risk of diabetes should be further investigated, there is insufficient evidence that an increased intake of this nutrient will prevent the disease.

\section{Magnesium}

Three large American cohort studies have reported a strong negative association between intake of magnesium and risk of type 2 diabetes. This was seen in the Health Professionals Follow-up Study carried out on men aged $40-75^{117}$, the Nurses Study carried out on women aged $40-65^{116}$, and the Iowa Women's Health Study carried out on women aged 55-69 ${ }^{161}$. In each case the protective association in the extreme quintiles revealed a risk ratio of about 0.7 , after correcting for related variables such as age, BMI, smoking and physical activity. While the association was attenuated after adjusting for cereal fibre, an important source of magnesium, the protective association remained strong and statistically significant. In contrast to these reports, no association was seen between magnesium intake and risk of type 2 diabetes in the ARIC study, a cohort study on men and women aged 45-64 ${ }^{195}$. However, this study was considerably smaller than the other three and, therefore, had much less statistical power. In the absence of any evidence regarding mechanisms of action, it seems inappropriate to offer recommendations regarding intake.

\section{Chromium}

The relationship between chromium and glucose metabolism has been under investigation since the late $1950 s^{196-198}$. Anderson et al. ${ }^{199}$ reported that subjects with mildly impaired IGT showed an improvement in 
glucose tolerance and a lower level of blood insulin after receiving chromium supplementation. This was not seen in subjects with normal glucose tolerance. The subjects had been consuming a low intake of chromium. This study suggests that when the intake of chromium is low, some people develop glucose intolerance, which can be corrected by chromium supplementation. The lowering in blood insulin level indicates that the chromium improves tissue sensitivity to insulin (i.e. helped reverse insulin insensitivity). Comparable observations have been reported from studies in rats ${ }^{200-202}$. A study undertaken with adults who already have type 2 diabetes showed improved glycaemic control with chromium supplements, compared with placebo $^{203}$.

\section{Alcohol intake}

Several studies have suggested that moderate alcohol intake is associated with a reduced incidence of type 2 diabetes. Among women in the Nurses Health Study, there was a reduced incidence of diabetes in women who consumed alcohol compared with those who did not. There was a strong inverse relation between alcohol consumption and body weight, which could explain much of the apparent protective effect of alcohol consumption $^{204}$. Among 20,000 male physicians, those consuming more than 2-4 drinks per week had a lower incidence of type 2 diabetes in the subsequent 12 years compared with non-drinkers, relationships that persisted after adjustment of BMI and other diabetes risk factors ${ }^{205,206}$.

These apparent male-female differences were examined among 12,000 45-64 year old participants in the Atherosclerosis Risk in Communities Study (ARIC) ${ }^{207}$. After adjustment for other diabetes risk factors men consuming more than 21 drinks per week had a significant increase in the incidence of diabetes, whereas no significant association with alcohol intake was found among the women. The apparent inconsistencies in the results of these studies preclude clear recommendations regarding alcohol in the prevention of diabetes.

\section{Intrauterine environment}

There has been much recent interest in the extent to which intrauterine environment may influence the subsequent risk of developing diabetes and other diseases. Gestational diabetes, which is a strong risk factor for development of type 2 diabetes, is also considered here because of its association with overweight in pregnancy and possible intrauterine factors, which may play a role in the offspring.

\section{Gestational diabetes}

Gestational diabetes (diabetes first recognised during pregnancy) is more frequent among women from subgroups of the population who have a high risk of type 2 diabetes, e.g. older, overweight or obese women, certain ethnic groups. In some cases, gestational diabetes represents diabetes that was present, but undiagnosed before pregnancy, whereas in others it develops during pregnancy, most frequently towards the end of the second trimester. It is in this latter group, that following delivery glucose tolerance is likely to become normal, but such women carry a high risk for developing diabetes subsequently ${ }^{208,209}$.

The intrauterine environment influences the risk of developing type 2 diabetes. Offspring of diabetic pregnancies are often large and heavy at birth; they tend to develop obesity in childhood and are at high risk of developing type 2 diabetes at an early age ${ }^{210}$. Such individuals have lower insulin secretion than similarly aged offspring of non-diabetic pregnancies ${ }^{211}$.

A substantial part of the excess risk of diabetes in the offspring of diabetic pregnancies appears to be the result of exposure to the diabetic intrauterine environment. Among offspring born to mothers before and after the development of type 2 diabetes, those born after the mother developed diabetes, have a 3-fold higher risk of developing diabetes than those born before ${ }^{212}$. Thus, the enhanced risk among the offspring from diabetic pregnancies among such women appears to be the result of intrauterine programming that has long-term effects on the offspring in later life. The early appearance of type 2 diabetes in female offspring increases the likelihood that their offspring in turn will be exposed to a diabetic intrauterine environment, leading to an increased prevalence of diabetes in subsequent generations.

\section{Intrauterine growth retardation and low birth weight}

Evidence that type 2 diabetes may be programmed during foetal development comes from numerous studies on adults $^{213-221}$. These showed an association between birth weight and abnormal glucose-insulin metabolism in later life. The prevalence of type 2 diabetes and IGT in adults was found to decrease from $40 \%$ by those who weighed $<2.54 \mathrm{~kg}$ to $14 \%$ among those who weighed $>4.31 \mathrm{~kg}$ at birth $^{213}$. In Pima Indians, this relationship was found to be U-shaped, with a high prevalence of diabetes also found in those who had a birth weight $>4.5 \mathrm{~kg}^{216}$. Additionally, the highest prevalence of type 2 diabetes was found in people who were small at birth and obese as adults ${ }^{213,218}$. Low birth weight is also associated with other traits that are associated with the development of diabetes including increased blood pressure, elevated triglycerides and lower HDL concentrations-all characteristic of the insulin resistance or metabolic syndrome ${ }^{222}$.

Studies in many populations indicate that low-birth weight babies have an increased risk of developing type 2 diabetes in adult life $\mathrm{e}^{213,223-226}$. This relationship was first described by Hales and Barker ${ }^{227}$ who suggested that low birth weight due to nutritional deprivation in utero resulted in reduced beta-cell mass. They suggested that the 
relationship might represent a 'thrifty phenotype'-an acquired rather than inherited defect-which was expressed as type 2 diabetes when those with the genotype were exposed to a more affluent nutritional environment $^{222}$.

It appears that foetal adaptations take place during times of undernutrition. Some organs and systems may be permanently altered or programmed to develop certain diseases later in life. Examples of this are the outcomes regarding adults who were in utero during the Dutch famine. They were about $200 \mathrm{~g}$ lighter at birth than those who were not exposed to the famine. As adults they show a reduced glucose tolerance and evidence of insulin resistance $^{228}$. Birth weight serves as a marker for foetal nutrition and growth ${ }^{229}$. There is evidence to suggest that thin babies are more likely to develop type 2 diabetes $^{214}$, as are short fat babies ${ }^{230}$.

It is important to appreciate that intrauterine growth retardation may not necessarily be due to deficiencies in maternal nutrition. A cohort study undertaken in Portsmouth on 693 nulliparous white women with singleton pregnancies showed that placental and infant birth weights were not associated with the intake of energy or any macronutrient intakes early or later in pregnancy ${ }^{231}$. The researchers suggest that among relatively well-nourished women in industrialised countries, maternal nutrition may only have a marginal effect on infant and placental size.

Animal studies have shown that a protein or energy deficient maternal diet can result in offspring having abnormal proportions at birth ${ }^{221}$. Two studies on the longterm effects of maternal diet in humans have indicated that the ratio of animal protein to carbohydrate may play a significant role in birth weight outcome ${ }^{232,233}$.

Thus, while intrauterine growth retardation would seem to be well established as a risk factor for the later development of diabetes, the precise role of maternal diet is less well established.

\section{Breastfeeding}

Early feeding may also play a role in subsequent development of type 2 diabetes in later life ${ }^{234-236}$. Bennett et $a{ }^{234}$ found that the prevalence of diabetes was about 50\% lower in Pima Indians who had been exclusively breastfed for the first 2 months of life. The mechanism for the protective effect of breastfeeding remains to be established and further confirmatory evidence is required.

\section{Other risk factors}

Several other risk factors have been related to the development of diabetes. These include several inflammatory markers (e.g. interleukin-6, C-reactive protein, other cytokines and acute phase reactants $)^{237-240}$ and variation in levels of sex hormones ${ }^{241-244}$ (e.g. low levels of sex hormone binding globulin in women, low testosterone levels in men and women with high androgen levels).

\section{Lifestyle modifications and risk reduction}

Three recent studies have examined the potential of lifestyle intervention programmes in reducing progression of IGT to diabetes. Two randomised controlled trials have demonstrated that weight loss achieved by an increase in physical activity and dietary change including reduction in total and saturated fat and increased dietary fibre can reduce the incidence of diabetes ${ }^{175,176}$. Other studies, which did not involve individual randomisation, provide confirmatory evidence ${ }^{245,246}$.

The aim of the Finnish Diabetes Prevention Study (FDPS $)^{175}$ was to assess the efficacy of an intensive dietexercise programme on prevention of type 2 diabetes in 522 adults with IGT. Overweight subjects were randomised either to an intervention group or to a control group. The intervention group received individual counselling with respect to diet, weight loss and physical activity. There was a significant difference in weight loss between the two groups after 1 year ( 4.2 versus $0.8 \mathrm{~kg}$ ) and after 2 years $(3.5$ versus $0.8 \mathrm{~kg}$ ) of intervention. The cumulative incidence of diabetes was $11 \%$ in the intervention group and $23 \%$ in the control group. During the trial the risk of diabetes was reduced by $58 \%(P<0.001)$ in the intervention group.

A similar intervention programme was undertaken in the United States on a larger sample of more than 3000 overweight adults with IGT ${ }^{176}$. Participants were representative of a variety of national groups resident in the United States. This study - the US Diabetes Prevention Program (DPP) - included an additional arm whereby some participants were randomised to the drug metformin. About 29\% of the DPP control group developed diabetes during the follow-up of 3 years. By contrast 22\% of the metformin arm and $14 \%$ of the diet and exercise group developed diabetes. Participants in the diet and exercise group achieved a $7 \%$ weight loss in the first year and generally sustained a $5 \%$ total loss for the duration of the study.

In both studies, the estimated risk reduction was about $58 \%$. While lifestyle intervention studies such as the FDPS $^{154}$ and the $\mathrm{DPP}^{176}$ have shown that quite modest changes can reduce the progression from IGT to diabetes by $50-60 \%$, it has not been clear as to whether it will be possible to translate these findings to larger cohorts or to maintain these lifestyle changes in the longer term.

The Da Qing Study ${ }^{245}$ was undertaken over a longer intervention period (6 years), than the FDPS and the DPP. The Da Qing Study differed from the FDPS and the DPP in that participants with IGT were randomised by intervention rather than as individuals, into a control group or into one of three interventions: diet only, exercise only, or diet and exercise, in order to test the effectiveness of diet and 
exercise separately. The cumulative incidence of diabetes after 6 years was $67.7 \%$ in the control group, $43.8 \%$ in the diet group, $41.1 \%$ in the exercise group and $46 \%$ in the diet plus exercise group. All the groups differed significantly from the control group $(p<0.05)$. Proportional hazards analyses adjusted for differences in baseline BMI and fasting glucose, were associated with $31 \%$ reduction in risk of developing diabetes with diet alone; $46 \%$ reduction in risk with exercise alone and $42 \%$ reduction in risk with diet and exercise.

These three studies (among others) provide evidence that risk of developing type 2 diabetes can be reduced by changes in lifestyle by adults who are at high risk for the disease. Although the average amount of weight lost was relatively small, the difference between the incidence of diabetes in the intervention groups and the control groups was substantial. The latter finding emphasises the importance of even a small reduction of weight loss in conjunction with increase in physical activity in the prevention of diabetes. In addition, some intervention studies have demonstrated benefits in terms of several cardiovascular risk factors in addition to improved glucose tolerance ${ }^{175,246,247}$.

While these trials are of enormous importance, it is nevertheless equally important to appreciate that even in the intensive intervention groups an appreciable proportion goes on to develop type 2 diabetes and that the number of individuals progressing to diabetes increases with time. It is not clear whether this is due to inability to sustain the necessary intensive lifestyle interventions or whether this is due to deteriorating $\beta$ cell function. It is well established that the increased insulin secretion evident prior to the development of hyperglycaemia starts to reduce even during the phase of IGT and declines progressively as the disease process continues, regardless of treatment. Thus, the greatest hope of truly 'preventing' type 2 diabetes probably lies not in identifying those with IGT but rather in implementing lifestyle intervention programmes in populations at large (especially those at high risk of type 2) or in individuals at the stage of insulin resistance.

\section{Recommendations and policy implications}

The enormous economic, social and personal cost of type 2 diabetes make a compelling case for prevention. In recent years, there has been much new evidence demonstrating the potentially preventable nature of type 2 diabetes, particularly by the implementation of lifestyle measures such as weight control and exercise. In view of this and the devastating health impact of the disease it seems prudent that primary prevention should be a major priority. Tables 1 and 2 summarise the current evidence and recommendations made with respect to the development of type 2 diabetes.
Since the 1970s there have been numerous health promotion projects that have attempted to encourage people to lead a healthier lifestyle. These have been carried out variously in the community, in doctors' offices or at the worksite. While some have achieved success, more often their impact on the lifestyle of the intended target audience has been rather limited. It seems likely that even a modest change in diet and exercise habits can be of considerable importance when extrapolated to the population.

In order to achieve maximum benefit from lifestyle interventions changes in government policies and legislation will be needed in addition to individual and community-based programmes ${ }^{248}$. This would include mandating more nutrition education in schools, banning the advertising of unhealthy products and subsidising healthy foods at the expense of less appropriate foods.

Despite much research on nutritional factors in the aetiology of type 2 diabetes, the risk associated with several individual nutrients is not entirely clear. Thus, evidence-based advice to governments and public health authorities emphasises the role of weight reduction in the overweight and obese and an increase in physical activity. This approach can also be expected to have a positive effect for prevention of other major non-communicable diseases such as cardiovascular disease and hypertension.

Many developing countries now report the onset of type 2 diabetes at an increasingly young age. This trend towards younger age of onset implies a huge additional burden to the individuals and society and necessitates a lifetime approach to prevention.

In making recommendations to governments regarding the prevention of type 2 diabetes, priority should be given to the following:

1. Promotion and evaluation of 'healthy' lifestyle programmes, which focus on the following aspects:

- Prevention and early treatment of overweight and obesity, particularly in high risk groups;

- Consumption of a nutrient-dense diet, which is low in fat, particularly saturated fat, and free sugars and high in NSPs.

- An active lifestyle, which includes regular physical activity of at least $1 \mathrm{hr} /$ day, and vigorous activity, which is required to reduce the risk of developing type 2 diabetes.

- Moderate alcohol intake and cessation of cigarette smoking.

- Demonstration projects in developing and developed countries since it is recognised that there is a paucity of data on the efficacy of communitybased lifestyle programmes. 
Table 1 Summary of level of evidence on lifestyle factors and risk of developing type 2 diabetes

\begin{tabular}{|c|c|c|c|}
\hline Evidence & Decreased risk & No relationship & Increased risk \\
\hline Convincing & $\begin{array}{l}\text { Voluntary weight loss in overweight and obese people } \\
\text { Physical activity }\end{array}$ & - & $\begin{array}{l}\text { Overweight and obesity**} \\
\text { Abdominal obesity }^{\star \star \star} \\
\text { Physical inactivity } \\
\text { Maternal diabetes } \dagger\end{array}$ \\
\hline Probable & $\mathrm{NSPs}^{*}$ & - & $\begin{array}{l}\text { Saturated fats } \\
\text { Intrauterine growth retardation (IUGR) }\end{array}$ \\
\hline Possible & $\begin{array}{l}n-3 \text { Fatty acids } \\
\text { Low glycaemic index foods } \\
\text { Exclusive breastfeeding } \ddagger\end{array}$ & - & $\begin{array}{l}\text { Total fat intake } \\
\text { Trans fatty acids }\end{array}$ \\
\hline Insufficient & $\begin{array}{l}\text { Vitamin E } \\
\text { Chromium } \\
\text { Magnesium } \\
\text { Moderate alcohol }\end{array}$ & - & Excess alcohol \\
\hline
\end{tabular}

${ }^{*}$ NSP - Non-starch polysaccharide.

** Overweight: BMI $\geq 25 \mathrm{~kg} / \mathrm{m}^{2}$, obesity: BMI $\geq 30 \mathrm{~kg} / \mathrm{m}^{2}$.

${ }^{\star * *}$ Waist circumference: men $\geq 102 \mathrm{~cm}$, women $\geq 88 \mathrm{~cm}$.

$\dagger$ This includes gestational diabetes.

$\ddagger$ As a global public health recommendation, infants should be exclusively breastfed for the first six months of life to achieve optimal growth, development and health.

Table 2 Summary of recommendations on diet and prevention of type 2 diabetes

\begin{tabular}{|c|c|c|}
\hline \multicolumn{2}{|c|}{ Risk factors } & \multirow[b]{2}{*}{$\begin{array}{l}\text { Recommendations } \\
\text { Prevention/early treatment of } \\
\text { overweight and obesity, } \\
\text { particularly in high risk groups } \\
\text { Avoid adult weight gain of }>5 \mathrm{~kg} \\
\text { The optimum BMI for individuals is } \\
\text { at the lower end of the } \\
\text { normal range } \\
\text { An optimum mean BMI for a } \\
\text { population is in the range of } \\
21-23 \mathrm{~kg} / \mathrm{m}^{2}\end{array}$} \\
\hline 1. & $\begin{array}{l}\text { Overweight/ } \\
\text { obesity }\end{array}$ & \\
\hline 2. & $\begin{array}{l}\text { Physical } \\
\text { inactivity }\end{array}$ & $\begin{array}{l}\text { Increase physical activity } \\
\text { (moderate or greater } \\
\text { level of intensity) to at least } \\
1 \mathrm{hr} \text { every day for most days } \\
\text { of the week } \\
\text { Vigorous activity is required to reduce } \\
\text { the risk of developing type } 2 \text { diabetes }\end{array}$ \\
\hline 3. & Fat intake & $\begin{array}{l}\text { Saturated fat intake should not exceed } \\
7 \% \text { of total energy intake in } \\
\text { high risk groups } \\
\text { Total fat intake should not exceed } \\
30 \% \text { of total energy intake }\end{array}$ \\
\hline 4. & NSPs & $\begin{array}{l}\text { Adequate intakes of NSPs can be } \\
\text { achieved through whole grain } \\
\text { cereals, legumes, vegetables and fruit }\end{array}$ \\
\hline 5. & $\begin{array}{l}\text { Further research } \\
\text { required on diet } \\
\text { and type } 2 \\
\text { diabetes }\end{array}$ & $\begin{array}{l}\text { Effect of maternal diet on infant } \\
\text { birth weight and subsequent } \\
\text { growth and development } \\
\text { Long-term effects of early stunting } \\
\text { Glycaemic index of different foods } \\
\text { (and in combination) } \\
n-3 \text { Fatty acids as protective factors } \\
\text { in decreasing risk of type } 2 \text { diabetes } \\
\text { Trans fatty acids as possible risk } \\
\text { factors for developing } \\
\text { type } 2 \text { diabetes } \\
\text { Benefits of exclusive breastfeeding } \\
\text { in reducing risk type } 2 \text { diabetes }\end{array}$ \\
\hline
\end{tabular}

NSP - Non-starch polysaccharide.
2. Early identification of subjects at risk of developing type 2 diabetes

- Identifying subjects at high risk of hypertension, diabetes and heart disease;

- Screening for gestational diabetes;

- Optimal maternal nutrition and weight maintenance.

3. Healthy lifestyle programmes/interventions should focus on a life course perspective and not on a specific age group or developmental stage.

4. Legislative action will be necessary to promote a healthier lifestyle for all populations. All governments and their employees in the social, health, nutritional, economic and welfare arenas should move forward on an integrated approach to the prevention of the disease and not only in treating the symptoms. There is compelling evidence for the benefits likely to accrue from policies and programmes aimed at reducing rates of overweight and obesity, at increasing physical activity and at reducing intake of saturated fatty acids. Individual countries, based on their national and individual food preferences, should develop dietary recommendations that are more specific in this regard.

\section{Acknowledgements}

An earlier version of this paper was prepared as a background paper for the Joint WHO/FAO Expert Consultation on diet, nutrition and the prevention of chronic diseases (Geneva, 28 January-1 February 2002). The authors wish to acknowledge the valuable contributions made by Professor NS Levitt, University of Cape Town, Cape Town, South Africa, Dr ARP Walker South African Institute for Medical Research, Johannesburg, 
South Africa, for critical reading and recommendations, and Ms Jean Fourie, MRC, Cape Town, South Africa, for technical support. The authors would also like to thank Professor K O’Dea, Menzies School of Health Research, Northern Territory, Australia; Dr H King, Department of Management of Noncommunicable Diseases, World Health Organization, Geneva, Switzerland, and Dr CS Yajnik, King Edward Memorial Hospital Research Centre, Mumbai, India for their valuable comments on the earlier manuscript.

\section{References}

1 King H, Aubert RE, Herman WH. Global burden of diabetes, 1995-2025: prevalence, numerical estimates, and projections. Diabetes Care 1998; 21: 1414-31.

2 Amos AF, McCarty DJ, Zimmet P. The rising global burden of diabetes and its complications: estimates and projections to the year 2010. Diabetic Medicine 1997; 14: S7-85.

3 Bennett PH. Type 2 diabetes among the Pima Indians of Arizona: an epidemic attributable to environmental change. Nutrition Reviews 1999; 57: S51-4.

4 Lako JV, Nguyen VC. Dietary patterns and risk factors of diabetes mellitus among urban indigenous women in Fiji. Asia Pacific Journal of Clinical Nutrition 2001; 10: 188-93.

5 Hetzel B, Michael T. The Lifestyle Factor: Lifestyle and Health. Melbourne: Penguin, 1987.

6 WHO Study Group. Diabetes Mellitus-Technical Report Series 727. Geneva: World Health Organization, 1985.

7 Gavin JR 3rd, Alberti KGMM, Davidson MB, et al. Report of the expert committee on the diagnosis and classification of diabetes mellitus. Diabetes Care 1997; 20: 1183-97.

8 WHO Consultation Group. Definition, Diagnosis and Classification of Diabetes Mellitus and its Complications. Part 1: Diagnosis and Classification of Diabetes Mellitus. Geneva: World Health Organisation, 1999.

9 Harris MI, Eastman RC, Cowie CC, Flegal KM, Eberhardt MS. Comparison of diabetes diagnostic categories in the US population according to the 1997 American Diabetes Association and 1980-1985 World Health Organization diagnostic criteria. Diabetes Care 1997; 20: 1859-62.

10 Bennett PH. Impact of the new WHO classification and diagnostic criteria. Diabetes Obesity \& Metabolism 1999; 1(Suppl. 2): S1-6

11 King H, Rewers M. Global estimates for prevalence of diabetes mellitus and impaired glucose tolerance in adults. WHO Ad Hoc Diabetes Reporting Group. Diabetes Care 1993; 16: 157-77.

12 Harris MI, Flegal KM, Cowie CC, Eberhardt MS, Goldstein DE, Little RR, Wiedmeyer HM, Byrd-Holt DD. Prevalence of diabetes, impaired fasting glucose, and impaired glucose tolerance in US adults. The Third National Health and Nutrition Examination Survey, 1988-1994. Diabetes Care 1998; 21: 518-24.

13 Harris MI, Hadden WC, Knowler WC, Bennett PH. Prevalence of diabetes and impaired glucose tolerance and plasma glucose levels in US population aged $20-74 \mathrm{yr}$. Diabetes 1987; 36: 523-34.

14 Harris MI. Noninsulin-dependent diabetes mellitus in black and white Americans. Diabetes-Metabolism Reviews 1990; 6: 71-90.

15 Flegal KM, Ezzati TM, Harris MI, Haynes SG, Juarez RZ, Knowler WC, Perez-Stable EJ, Stern MP. Prevalence of diabetes in Mexican Americans, Cubans, and Puerto Ricans from the Hispanic Health and Nutrition Examination Survey, 1982-1984. Diabetes Care 1991; 14: 628-38.

16 Gohdes D. Diabetes in North American Indians and
Alaska natives. In: Harris MI, Cowie CC, Stern MP, eds. Diabetes in America. Washington, USA. National Institutes of Health, 1995.

17 Knowler WC, Pettitt DJ, Saad MF, Bennett PH. Diabetes Mellitus in the Pima Indians: incidence, risk factors and pathogenesis. Diabetes-Metabolism Reviews 1990; 6: 1-27.

18 Mokdad AH, Bowman BA, Engelgau MM, Vinicor F. Diabetes trends among American Indians and Alaska natives: 1990-1998. Diabetes Care 2001; 24: 1508-9.

19 Mokdad AH, Bowman BA, Ford ES, Vinicor F, Marks JS, Koplan JP. The continuing epidemics of obesity and diabetes in the United States. Journal of the American Medical Association 2001; 286: 1195-200.

20 Teuscher T, Baillod P, Rosman JB, Teuscher A. Absence of diabetes in a rural West African population with a high carbohydrate/cassava diet. Lancet 1987; i: 765-8.

21 Walker ARP. Prevalence of diabetes mellitus. Lancet 1966; $\mathbf{i}$ : 1163 .

22 Cosnett JE. Illness among Natal Indians: a survey of hospital admissions. South African Medical Journal 1957; 31 : 1109-15.

23 Omar MAK, Seedat MA, Motala AA, Dyer RB, Becker P. The prevalence of diabetes mellitus and impaired glucose tolerance in a group of urban South African blacks. South African Medical Journal 1993; 83: 641-3.

24 Knowler WC, Bennett PH, Hamman RF, Miller M. Diabetes incidence and prevalence in Pima Indians: a 19-fold greater incidence than in Rochester, Minnesota. American Journal of Epidemiology 1978; 108: 497-505.

25 Knowler WC, Pettitt DJ, Savage PJ, Bennett PH. Diabetes incidence in Pima Indians: contributions of obesity and parental diabetes. American Journal of Epidemiology 1981; 113: $144-56$.

26 Dowse GK, Zimmet PZ, Finch CF, Collins VR. Decline in incidence of epidemic glucose intolerance in Nauruans: implications for the "thrifty genotype". American Journal of Epidemiology 1991; 133: 1093-104.

27 Bennett $\mathrm{PH}$, Knowler WC. Increasing prevalence of diabetes in the Pima (American) Indians over a ten-year period. In: Waldhausl WK, ed. Diabetes 1979. Amsterdam: Excerpta Medica, 1979.

28 Kleinman JC, Donahue RP, Harris MI, Finucane FF, Madans JH, Brock DB. Mortality among diabetics in a national sample. American Journal of Epidemiology 1988; 128: 389-401.

29 Gu K, Cowie CC, Harris MI. Mortality in adults with and without diabetes in a national cohort of the US population, 1971-1993. Diabetes Care 1998; 21: 1138-45.

30 Roper NA, Bilous RW, Kelly WF, Unwin NC, Connolly VM. Excess mortality in a population with diabetes and the impact of material deprivation: longitudinal, population based study. British Medical Journal 2001; 322: 1389-93.

31 Morrish NJ, Wang SL, Stevens LK, Fuller JH, Keen H. Mortality and causes of death in the WHO multinational study of vascular disease in diabetes. Diabetologia 2001; 44: S14-21.

32 Sievers ML, Nelson RG, Knowler WC, Bennett PH. Impact of NIDDM on mortality and causes of death in Pima Indians. Diabetes Care 1992; 15: 1541-9.

33 McLarty DG, Kinabo L, Swai AB. Diabetes in tropical Africa: a prospective study, 1981-7. II. Course and prognosis. British Medical Journal 1990; 300: 1107-10.

34 Bale GS, Entmacher PS. Estimated life expectancy of diabetics. Diabetes 1977; 26: 434-8.

35 Barrett-Connor E, Wingard DL. Sex differential in ischemic heart disease mortality in diabetics: a prospective population-based study. American Journal of Epidemiology 1983; 118: 489-96.

36 Hu FB, Stampfer MJ, Solomon CG, Liu S, Willett WC, Speizer FE, Nathan DM, Manson JE. The impact of diabetes 
mellitus on mortality from all causes and coronary heart disease in women: 20 years of follow-up. Archives of Internal Medicine 2001; 161: 1717-23.

37 Stamler J, Vaccaro O, Neaton JD, Wentworth D. Diabetes, other risk factors, and 12 -yr cardiovascular mortality for men screened in the multiple risk factor intervention trial. Diabetes Care 1993; 16: 434-44.

38 Saad MF, Knowler WC, Pettitt DJ, Nelson RG, Charles MA, Bennett PH. A two-step model for development of noninsulin-dependent diabetes. American Journal of Medicine 1991; 90: 229-35.

39 Saad MF, Knowler WC, Pettitt DJ, Nelson RG, Mott DM, Bennett PH. Sequential changes in serum insulin concentration during development of non-insulin-dependent diabetes. Lancet 1989; i: $1356-9$.

40 Shaw JE, Zimmet PZ, de Courten M, Dowse GK, Chitson P, Gareeboo H, Hemraj F, Fareed D, Tuomilehto J, Alberti KG. Impaired fasting glucose or impaired glucose tolerance. What best predicts future diabetes in Mauritius? Diabetes Care 1999; 22: 399-402.

41 Gabir MM, Hanson RL, Dabelea D, Imperatore G, Roumain J, Bennett PH, Knowler WC. The 1997 American Diabetes Association and 1999 World Health Organization criteria for hyperglycemia in the diagnosis and prediction of diabetes. Diabetes Care 2000; 23: 1108-12.

42 De Vegt F, Dekker JM, Jager A, Hienkens E, Kostense PJ, Stehouwer CD, Nijpels G, Bouter LM, Heine RJ. Relation of impaired fasting and postload glucose with incident type 2 diabetes in a Dutch population: the Hoorn Study. Journal of the American Medical Association 2001; 285: 2109-13.

43 Saad MF, Knowler WC, Pettitt DJ, Nelson RG, Mott DM, Bennett PH. The natural history of impaired glucose tolerance in the Pima Indians. New England Journal of Medicine 1988; 319: 1500-6.

44 Edelstein SL, Knowler WC, Bain RP, Andres R, BarrettConnor EL, Dowse GK, Haffner SM, Pettitt DJ, Sorkin JD, Muller DC, Collins VR, Hamman RF. Predictors of progression from impaired glucose tolerance to NIDDM: an analysis of six prospective studies. Diabetes 1997; 46: 701-10.

45 Weyer C, Bogardus C, Mott DM, Pratley RE. The natural history of insulin secretory dysfunction and insulin resistance in the pathogenesis of type 2 diabetes mellitus. Journal of Clinical Investigation 1999; 104: 787-94.

46 Eschwege E, Charles MA, Simon D, Thibult N, Balkau B. From policemen to policies: what is the future for 2 -h glucose?: The Kelly West Lecture, 2000. Diabetes Care 2001; 24: $1945-50$

47 Balkau B. The DECODE study. Diabetes epidemiology: collaborative analysis of diagnostic criteria in Europe. Diabetes \& Metabolism 2000; 26: 282-6.

48 Gabir MM, Hanson RL, Dabelea D, Imperatore G, Roumain J, Bennett PH, Knowler WC. Plasma glucose and prediction of microvascular disease and mortality: evaluation of 1997 American Diabetes Association and 1999 World Health Organization criteria for diagnosis of diabetes. Diabetes Care 2000; 23: 1113-8.

49 Shaw JE, Hodge AM, de Courten M, Chitson P, Zimmet PZ Isolated post-challenge hyperglycaemia confirmed as a risk factor for mortality. Diabetologia 1999; 42: 1050-4

50 Davies MJ, Raymond NT, Day JL, Hales CN, Burden AC. Impaired glucose tolerance and fasting hyperglycaemia have different characteristics. Diabetic Medicine 2000; 17 $433-40$.

51 Tan CE, Emmanuel SC, Tan BY, Jacob E. Prevalence of diabetes and ethnic differences in cardiovascular risk factors. The 1992 Singapore National Health Survey. Diabetes Care 1999; 22: 241-7.

52 Mather HM, Chaturvedi N, Fuller JH. Mortality and morbidity from diabetes in South Asians and Europeans: 11-year follow-up of the Southall Diabetes Survey, London, UK. Diabetic Medicine 1998; 15: 53-9.

53 Zimmet P, Taylor R, Ram P, King H, Sloman G, Raper LR, Hunt D. Prevalence of diabetes and impaired glucose tolerance in the biracial (Melanesian and Indian) population of Fiji: a rural-urban comparison. American Journal of Epidemiology 1983; 118: 673-88.

54 Omar MA, Seedat MA, Dyer RB, Motala AA, Knight LT, Becker PJ. South African Indians show a high prevalence of NIDDM and bimodality in plasma glucose distribution patterns. Diabetes Care 1994; 17: 70-3

55 Prior IA, Davidson F. The epidemiology of diabetes in Polynesians and Europeans in New Zealand and the Pacific. New Zealand Medical Journal 1966; 65: 375-83.

56 Simmons D. The epidemiology of diabetes and its complications in New Zealand. Diabetic Medicine 1996; 13: 371-5.

57 Everhart JE, Knowler WC, Bennett PH. Incidence and risk factors for noninsulin-dependent diabetes. In: Harris MI, Hamman RF, eds. Diabetes in America, Diabetes Data Compiled 1984. 1985 NIH Publication No. 85-1468.

58 Barnett AH, Eff C, Leslie RD, Pyke DA. Diabetes in identical twins. A study of 200 pairs. Diabetologia 1981; 20: 87-93.

59 Newman B, Selby JV, King MC, Slemenda C, Fabsitz R, Friedman GD. Concordance for type 2 (non-insulindependent) diabetes mellitus in male twins. Diabetologia 1987; 30: 763-8.

60 Serjeantson SW, Owerbach D, Zimmet P, Nerup J, Thoma K Genetics of diabetes in Nauru: effects of foreign admixture, HLA antigens and the insulin-gene-linked polymorphism. Diabetologia 1983; 25: 13-7.

61 Knowler WC, Williams RC, Pettitt DJ, Steinberg AG. Gm3;5,13,14 and type 2 diabetes mellitus: an association in American Indians with genetic admixture. American Journal of Human Genetics 1988; 43: 520-6.

62 Gardner LI Jr, Stern MP, Haffner SM, Gaskill SP, Hazuda HP, Relethford JH, Eifler CW. Prevalence of diabetes in Mexican Americans. Relationship to percent of gene pool derived from native American sources. Diabetes 1984; 33: 86-92.

63 Kenny SJ, Aubert RE, Geiss LS. Prevalence and incidence of non-insulin-dependent diabetes. In: Harris MI, Cowie CC, Stern MP, eds. Diabetes in America. Washington, USA. National Institutes of Health, 1995.

64 Dabelea D, Hanson RL, Bennett PH, Roumain J, Knowler WC, Pettitt DJ. Increasing prevalence of Type II diabetes in American Indian children. Diabetologia 1998; 41: 904-10.

65 Fagot-Campagna A, Pettitt DJ, Engelgau MM, Burrows NR, Geiss LS, Valdez R, Beckles GL, Saaddine J, Gregg EW, Williamson DF, Narayan KM. Type 2 diabetes among North American children and adolescents: an epidemiologic review and a public health perspective. Journal of Pediatrics 2000; 136: 664-72.

66 Dean HJ, Mundy RL, Moffatt M. Non-insulin-dependent diabetes mellitus in Indian children in Manitoba. Canadian Medical Association Journal 1992; 147: 52-7.

67 Kitagawa T, Owada M, Urakami T, Yamauchi K. Increased incidence of non-insulin dependent diabetes mellitus among Japanese schoolchildren correlates with an increased intake of animal protein and fat. Clinical Pediatrics (Philadelphia) 1998; 37: 111-5.

68 Savage PJ, Bennett PH, Senter RG, Miller M. High prevalence of diabetes in young Pima Indians: evidence of phenotypic variation in a genetically isolated population. Diabetes 1979; 28: 937-42

69 Colditz GA, Willett WC, Stampfer MJ, Manson JE, Hennekens $\mathrm{CH}$, Arky RA, Speizer FE. Weight as a risk factor for clinical diabetes in women. American Journal of Epidemiology 1990; 132: 501-13

70 Kuczmarski RJ, Flegal KM, Campbell SM, Johnson CL. Increasing prevalence of overweight among US adults. The National Health and Nutrition Examination Surveys, 
1960 to 1991. Journal of the American Medical Association 1994; 273: 205-11.

71 Shah M, Hannan PJ, Jeffery RW. Secular trend in body mass index in the adult population of three communities from the upper mid-western part of the USA: the Minnesota Heart Health Program. International Journal of Obesity 1991; 15: 499-503.

72 Federation of American Societies for Experimental Biology Life Sciences Research Office. Third Report on Nutrition Monitoring in the United States. Washington, DC: US Government Printing Office, 1995.

73 Bouchard C, Tremblay A, Despres JP, Nadeau A, Lupien PJ, Theriault G, Dussault J, Moorjani S, Pinault S, Fournier G. The response to long-term overfeeding in identical twins. New England Journal of Medicine 1990; 322: 1477-82.

74 Preparation and Use of Food-based Dietary Guidelines. Report of a Joint FAO/WHO Consultation. WHO Technical Report Series No. 880. Geneva: World Health Organization, 1998.

75 Schoeller DA. The importance of clinical research: the role of thermogenesis in human obesity. American Journal of Clinical Nutrition 2001; 73: 511-6.

76 Grundy SM. Multifactorial causation of obesity: implications for prevention. American Journal of Clinical Nutrition 1998; 67(Suppl.): 563S-72S.

77 Ravussin E, Swinburn BA. Pathophysiology of obesity. Lancet 1992; 340: 404-8.

78 National Institutes of Health. The Lipid Research Clinics Population Studies Data Book: The Prevalence Study. (Publication no. 79-1527) Bethesda, MD: NIH, 1979.

79 Flatt JP. Importance of nutrient balance in body weight regulation. Diabetes-Metabolism Reviews 1988; 4: 571-81.

80 Shah M, Garg A. High-fat and high-carbohydrate diets and energy balance. Diabetes Care 1996; 19: 1142-52.

81 Sclafani A. Dietary obesity models. In: Bjorntorp P, Brodoff BN, eds. Obesity. Philadelphia, PA: JB Lippincott, 1992, 241-8

82 Anonymous. From the Centers for Disease Control and Prevention: daily dietary fat and total food energy intakes: NHANES III, Phase 1, 1988-91. Journal of the American Medical Association 1994; 271: 1309.

83 Swinburn B, Metcalf P, Lezotte DC. Long-term (5-year) effects of a reduced fat diet in individuals with glucose intolerance. Diabetes Care 2001; 24: 619-24.

84 Astrup A, Greenwald G, Melanson E, Saris WH, Hill J. The role of low-fat diets in body weight control:a meta-analysis of ad libitum dietary intervention studies. International Journal of Obesity 2000; 24: 1545-52.

85 Chan JM, Rimm EB, Colditz GA, Stampfer MJ, Willett WC. Obesity, fat distribution, and weight gain as risk factors for clinical diabetes in men. Diabetes Care 1994; 17: 961-9.

86 Boyko EJ, Fujimoto WY, Leonetti DL, Newell-Morris L. Visceral adiposity and risk of type 2 diabetes: a prospective study among Japanese Americans. Diabetes Care 2000; 23: 465-71.

87 Despres JP. Health consequences of visceral obesity. Annals of Medicine 2001; 33: 534-41.

88 James WPT, Leach R, Kalamara E, Shayeghi M. The worldwide obesity epidemic. Obesity Research 2001; 9: 228S-33S.

89 Manson JE, Rimm EB, Stampfer MJ, Colditz GA, Willett WC, Krolewski AS, Rosner B, Hennekens CH, Speizer FE. Physical activity and incidence of non-insulin-dependent diabetes mellitus in women. Lancet 1991; 338: 774-8.

90 Manson JE, Nathan DM, Krolewski AS, Stampfer MJ, Willett WC, Hennekens CH. A prospective study of exercise and incidence of diabetes among US male physicians. Journal of the American Medical Association 1992; 268: 63-7.

91 Kriska AM, LaPorte RE, Pettitt DJ, Charles MA, Nelson RG, Kuller LH, Bennett PH, Knowler WC. The association of physical activity with obesity, fat distribution and glucose intolerance in Pima Indians. Diabetologia 1993; 36: 863-9.

92 Helmrich SP, Ragland DR, Leung RW, Paffenbarger RS Jr. Physical activity and reduced occurrence of non-insulindependent diabetes mellitus. New England Journal of Medicine 1991; 325: 147-52.

93 McAuley KA, Williams SM, Mann JI, Goulding A, Chisholm A, Wilson N, Story G, McLay RT, Harper MJ, Jones IE. Intensive lifestyle changes are necessary to improve insulin sensitivity: a randomized controlled trial. Diabetes Care 2002; 25: 445-52.

94 Storlien LH, Baur LA, Kriketos AD, Pan DA, Cooney GJ, Jenkins AB, Calvert GD, Campbell LV. Dietary fats and insulin action. Diabetologia 1996; 39: 621-31.

95 Lichtenstein AH, Schwab US. Relationship of dietary fat to glucose metabolism. Atherosclerosis 2000; 150: 227-43.

$96 \mathrm{Hu}$ FB, van Dam RM, Liu S. Diet and risk of type II diabetes: the role of types of fat and carbohydrate. Diabetologia 2001; 44: 805-17.

97 Nagy K, Levy J, Grunberger G. High-fat feeding induces tissue-specific alteration in proportion of activated insulin receptors in rats. Acta Endocrinologica Copenhagen 1990; 122: $361-8$

98 Grundleger ML, Thenen SW. Decreased insulin binding, glucose transport, and glucose metabolism in soleus muscle of rats fed a high fat diet. Diabetes 1982; 31: 232-7.

99 Hedeskov CJ, Capito K, Islin H, Hansen SE, Thams P. Longterm fat-feeding-induced insulin resistance in normal NMRI mice: postreceptor changes of liver, muscle and adipose tissue metabolism resembling those of type 2 diabetes. Acta Diabetologica 1992; 29: 14-9.

100 Storlien LH, Jenkins AB, Chisholm DJ, Pascoe WS, Khouri S, Kraegen EW. Influence of dietary fat composition on development of insulin resistance in rats. Relationship to muscle triglyceride and omega- 3 fatty acids in muscle phospholipid. Diabetes 1991; 40: 280-9.

101 Pan DA, Lillioja S, Kriketos AD, Milner MR, Baur LA, Bogardus C, Jenkins AB, Storlien LH. Skeletal muscle triglyceride levels are inversely related to insulin action. Diabetes 1997; 46: 983-8.

102 Storlien LH, James DE, Burleigh KM, Chisholm DJ, Kraegen EW. Fat feeding causes widespread in vivo insulin resistance, decreased energy expenditure, and obesity in rats. American Journal of Physiolgy 1986; 251: E576-83.

103 Storlien LH, Kraegen EW, Chisholm DJ, Ford GL, Bruce DG, Pascoe WS. Fish oil prevents insulin resistance induced by high-fat feeding in rats. Science 1987; 237: 885-8.

104 Marshall JA, Hamman RF, Baxter J. High-fat, lowcarbohydrate diet and the aetiology of non-insulindependent diabetes mellitus: the San Luis Valley Diabetes Study. American Journal of Epidemiology 1991; 134: 590-603.

105 Moses RG, Shand JL, Tapsell LC. The recurrence of gestational diabetes: could dietary differences in fat intake be an explanation? Diabetes Care 1997; 20: 1647-50.

106 Feskens EJM, Virtanen SM, Räsänen L, Tuomilehto J, Stengård J, Pekkanen J, Nissinen A, Kromhout D. Dietary factors determining diabetes and impaired glucose tolerance. A 20-year follow-up of the Finnish and Dutch cohorts of the Seven Countries Study. Diabetes Care 1995; 18: $1104-12$.

107 Marshall JA, Hoag S, Shetterly S, Hamman RF. Dietary fat predicts conversion from impaired glucose tolerance to NIDDM. The San Luis Valley Diabetes Study. Diabetes Care 1994; 17: 50-6.

108 Marshall JA, Bessesen DH, Hamman RF. High saturated fat and low starch and fibre are associated with hyperinsulinemia in a non-diabetic population: the San Luis Valley Diabetes Study. Diabetologia 1997; 40: 430-8.

109 Mayer EJ, Newman B, Quesenberry CP, Selby JV. Usual 
dietary fat intake and insulin concentrations in healthy women twins. Diabetes Care 1993; 16: 1459-69.

110 Lovejoy J, DiGirolamo M. Habitual dietary intake and insulin sensitivity in lean and obese adults. American Journal of Clinical Nutrition 1992; 55: 1174-9.

111 Bennett P, Knowler W, Baird H, Butler W, Pettitt D, Reid J. Diet and development of non-insulin-dependent diabetes mellitus: an epidemiological perspective. In: Pozza B, ed.. Diet, Diabetes and Atherosclerosis. . New York: Raven Press, 1984, 109-19.

112 Lundgren H, Bengtsson C, Blohme G, Isaksson B, Lapidus L, Lenner RA, Saaek A, Winther E. Dietary habits and incidence on noninsulin-dependent diabetes mellitus in a population study of women in Gothenburg, Sweden. American Journal of Clinical Nutrition 1989; 49: 708-12.

113 Feskens EJ, Kromhout D. Cardiovascular risk factors and the 25-year incidence of diabetes mellitus in middle-aged men. The Zutphen Study. American Journal of Epidemiology 1989; 130: 1101-8.

114 Feskens EJ, Bowles CH, Kromhout D. Inverse association between fish intake and risk of glucose intolerance in normoglycemic elderly men and women. Diabetes Care 1991; 14: 935-41.

115 Colditz GA, Manson JE, Stampfer MJ, Rosner B, Willett WC, Speizer FE. Diet and risk of clinical diabetes in women. American Journal of Clinical Nutrition 1992; 55: 1018-23.

116 Salmeron J, Manson JE, Stampfer MJ, Colditz GA, Wing AL, Willett WC. Dietary fiber, glycemic load, and risk of noninsulin-dependent diabetes mellitus in women. Journal of the American Medical Association 1997; 277: 472-7.

117 Salmeron J, Ascherio A, Rimm EB, Colditz GA, Spiegelman D, Jenkins DJ, Stampfer MJ, Wing AL, Willett WC. Dietary fiber, glycemic load and risk of NIDDM in men. Diabetes Care 1997; 20: 545-50.

118 Salmeron J, Hu FB, Manson JE, Stampfer MJ, Colditz GA, Rimm EB, Willett WC. Dietary fat intake and risk of type 2 diabetes in women. American Journal of Clinical Nutrition 2001; 73: 1019-26.

119 Meyer KA, Kushi LH, Jacobs DR, Folsom AR. Dietary fat and incidence of type 2 diabetes in older Iowa women. Diabetes Care 2001; 24: 1528-35.

120 Kolterman OG, Greenfield M, Reaven GM, Saekow M, Olefsky JM. Effect of a high carbohydrate diet on insulin binding to adipocytes and on insulin action in vivo in man. Diabetes 1979; 28: 731-6.

121 Beck-Nielsen H, Pedersen O, Sorensen N. Effects of diet on the cellular insulin binding and the insulin sensitivity in young healthy subjects. Diabetologia 1978; 15: 289-96.

122 Borkman M, Campbell LV, Chisholm DJ, Storlien LH Comparison of the effects on insulin sensitivity of high carbohydrate and high fat diets in normal subjects. Journal of Clinical Endocrinology \& Metabolism 1991; 72: 432-7.

123 Hjollund E, Pedersen O, Richelsen B, Beck-Nielsen H, Sorensen NS. Increased insulin binding to adipocytes and monocytes and increased insulin sensitivity of glucose transport and metabolism in adipocytes from non-insulindependent diabetics after a low-fat/high-starch/high-fiber diet. Metabolism 1983; 32: 1067-75.

124 Chen M, Bergman RN, Porte D. Insulin resistance and betacell dysfunction in aging: the importance of dietary carbohydrate. Journal of Clinical Endocrinology \& Metabolism 1988; 67: 951-7.

125 Swinburn BA, Boyce VL, Bergman RN, Howard BV, Bogardus C. Deterioration in carbohydrate metabolism and lipoprotein changes induced by modern, high fat diet in Pima Indians and Caucasians. Journal of Clinical Endocrinology \& Metabolism 1991; 73: 156-65.

126 Lovejoy JC, Windhauser MM, Rood JC, de la Bretonne JA Effect of a controlled high-fat versus low-fat diet on insulin sensitivity and leptin levels in African-American and Caucasian women. Metabolism 1998; 47: 1520-4.

127 Bisschop PH, de Metz J, Ackermans MT, Endert E, Pijl H, Kuipers F, Meijer AJ, Sauerwein HP, Romijn JA. Dietary fat content alters insulin-mediated glucose metabolism in healthy men. American Journal of Clinical Nutrition 2001; 73: 554-9.

128 Bo S, Menato G, Lezo A, Signorile A, Bardelli C, De Michieli F, Massobrio M, Pagano G. Dietary fat and gestational hyperglycemia. Diabetologia 2001; 44: 972-8.

129 Feskens EJ, Kromhout D. Habitual dietary intake and glucose tolerance in euglycaemic men: the Zutphen study. International Journal of Epidemiology 1990; 19: 953-9.

130 Trevisan M, Krogh V, Freudenheim J, Blake A, Muti P, Panico S, Farinaro E, Mancini M, Menotti A, Ricci G. Consumption of olive oil, butter and vegetable oils and coronary heart disease risk factors. The Research Group ATS-RF2 of the Italian National Research Council. Journal of the American Medical Association 1990; 263: 688-92.

131 Parker DR, Weiss ST, Troisi R, Cassano PA, Vokonas PS, Landsberg L. Relationship of dietary saturated fatty acids and body habitus to serum insulin concentrations: the Normative Aging study. American Journal of Clinical Nutrition 1993; 58: 129-36.

132 Folsom AR, Ma J, McGovern PG, Eckfeldt H. Relation between plasma phospholipid saturated fatty acids and hyperinsulinemia. Metabolism 1996; 45: 223-8.

133 Vessby B, Tengblad S, Lithell $\mathrm{H}$. Insulin sensitivity is related to the fatty acid composition of serum lipids and skeletal muscle phospholipids in 70-year-old men. Diabetologia 1994; 37: 1044-50.

134 Vessby B, Aro A, Skarfors E, Berglund L, Salminen I, Lithell $\mathrm{H}$. The risk to develop NIDDM is related to the fatty acid composition of the serum cholesterol esters. Diabetes 1994; 43: $1353-7$.

135 Mooy JM, Grootenhuis PA, de Vries H, Valkenburg HA, Bouter LM, Kostense PJ, Heine RJ. Prevalence and determinants of glucose intolerance in a Dutch caucasian population. The Hoorn study. Diabetes Care 1995; 18 $1270-3$.

136 Borkman M, Storlien LH, Pan DA, Jenkins AB, Chisholm DJ, Campbell LV. The relation between insulin sensitivity and the fatty-acid composition of skeletal-muscle phospholipids. New England Journal of Medicine 1993; 328: 238-44.

137 Pan DA, Lillioja S, Milner MR, Kriketos AD, Baur LA Bogardus C, Storlien LH. Skeletal muscle membrane lipid composition is related to adiposity and insulin action. Journal of Clinical Investigation 1995; 96: 2802-8.

138 Maron DJ, Fair JM, Haskell WL. Saturated fat intake and insulin resistance in men with coronary artery disease. The stanford coronary risk intervention project investigators and staff. Circulation 1991; 84: 2020-7.

139 Uusitupa M, Schwab U, Mäkimattila S, Karhapää P, Sarkkinen E, Maliranta H, Ågren J, Penttilä I. Effects of two high-fat diets with different fatty acid compositions on glucose and lipid metabolism in healthy young women. American Journal of Clinical Nutrition 1994; 59: 1310-6.

140 Vessby B, Gustafsson I-B, Boberg J, Karlström B, Lithell H, Werner I. Substituting polyunsaturated for saturated fat as a single change in a Swedish diet: effects on serum lipoprotein metabolism and glucose tolerance in patients with hyperlipoproteinaemia. European Journal of Clinical Investigation 1980; 10: 193-202.

141 Vessby B, Uusitupa M, Hermansen K, Riccardi G, Rivellese AA, Tapsell LC, Nälsen C, Berglund L, Louheranta A, Rasmussen BM, Calvert GD, Maffettone A, Pedersen E, Gustafsson I-B, Storlien LH. Substituting dietary saturated for monounsaturated fat impairs insulin sensitivity in healthy men and women: the KANWU study. Diabetologia 2001; 44: 312-9. 
142 Schwab US, Niskanen LK, Maliranta HM, Savolainen MJ, Kesäniemi YA, Uusitupa MIJ. Lauric and palmitic acidenriched diets have minimal impact on serum lipid and lipoprotein concentrations and glucose metabolism in healthy young women. Journal of Nutrition 1995; 125: 466-73.

143 Louheranta AM, Turpeinen AK, Schwab US, Vidgren HM, Parviainen MT, Uusitupa MIJ. A high-stearic acid diet does not impair glucose tolerance and insulin sensitivity in healthy women. Metabolism 1998; 47: 529-34.

144 Alstrup KK, Gregersen S, Jensen HM, Thomsen JL, Hermansen K. Differential effects of cis and trans fatty acids on insulin release from isolated mouse islets. Metabolism 1999; 48: 22-9.

145 Christiansen E, Schnider S, Palmvig B, Tauber-Lassen E, Pedersen $O$. Intake of a diet high in trans monounsaturated fatty acids or saturated fatty acids. Effects of postprandial insulinemia and glycemia in obese patients with NIDDM. Diabetes Care 1997; 20: 881-7.

146 Louheranta AM, Turpeinen AK, Vidgren HM, Schwab US, Uusitupa MIJ. A high-trans fatty acid diet and insulin sensitivity in young healthy women. Metabolism 1999; 48 $870-5$.

147 Borkman M, Chisholm DJ, Furler SM, Storlien LH, Kraegen EW, Simons LA, Chesterman CN. Effects of fish-oil supplementation on glucose and lipid metabolism in NIDDM. Diabetes 1989; 38: 1314-9.

148 Annuzzi G, Rivellese A, Capaldo B, Di Marino L, Iovine C, Marotta G, Riccardi G. A controlled study on the effects of $n-3$ fatty acids on lipid and glucose metabolism in noninsulin-dependent diabetic patients. Atherosclerosis 1991; 87: $65-73$.

149 Boberg M, Pollare T, Siegbahn A, Vessby B. Supplementation with $n-3$ fatty acids reduces triglycerides but increases PAI-1 in non-insulin-dependent diabetes mellitus. European Journal of Clinical Investigation 1992; 22: 645-50.

150 McManus RM, Jumpson J, Finegood DT, Clandinin MT, Ryan EA. A comparison of the effects of $n-3$ fatty acids from linseed oil and fish oil in well controlled type II diabetes. Diabetes Care 1996; 19: 463-7.

151 Rivellese AA, Maffettone A, Iovine C, Di Marino L, Annuzzi G, Mancini M, Riccardi G. Long-term effects of fish oil on insulin resistance and plasma lipoproteins in NIDDM patients with hypertriglyceridemia. Diabetes Care 1996; 19: 1207-13.

152 Grundy SM. The optimal ratio of fat-to-carbohydrate in the diet. Annual Review of Nutrition 1999; 19: 325-41.

153 Bray GA, Popkin BM. Dietary fat intake does affect obesity. American Journal of Clinical Nutrition 1998; 68: 1157-73.

154 Richards MK, Paeratakul S, Bray GA, Popkin BM. Current theories regarding the influence of diet and the control of obesity. In: Wilson T, Temple NJ, eds. Nutritional Health: Strategies for Disease Prevention. Totowa, NJ: Human Press Inc., 2001, 135-50.

155 Tsunehara CH, Leonetti DL, Fujimoto WY. Diet of secondgeneration Japanese-American men with and without non-insulin-dependent diabetes. American Journal of Clinical Nutrition 1990; 52: 731-8.

156 Grundy SM, Denke M. Dietary influences on serum lipids and lipoproteins. Journal of Lipid Research 1990; 31: 1149-72.

157 Nestle PJ, Carroll KF, Havenstein N. Plasma triglyceride response to carbohydrates, fats and caloric intake. Metabolism 1970; 19: 1-18.

158 Mensink RP, Katan MB. Effect of dietary fatty acids on serum lipids and lipoproteins: a meta-analysis of 27 trials. Arteriosclerosis and Thrombosis 1992; 12: 911-9.

159 Jeppesen J, Schaaf P, Jones C, Zhou MY, Chen YD, Reaven GM. Effects of low-fat, high-carbohydrate diets on risk factors for ischemic heart disease in postmenopausal women. American Journal of Clinical Nutrition 1997; 65: 1027-33.

160 Parks EJ, Hellerstein MK. Carbohydrate-induced hypertriacylglycerolemia: historical perspective and review of biological mechanisms. American Journal of Nutrition 2000; 71: 412-33

161 Meyer KA, Kushi LH, Jacobs DR, Slavin J, Sellers TA, Folsom AR. Carbohydrates, dietary fiber, and incident type 2 diabetes in older women. American Journal of Clinical Nutrition 2000; 71: 921-30.

162 Bessesen DH. The role of carbohydrates in insulin resistance. Journal of Nutrition 2001; 131: 2782S-6S.

163 Reaven GM. Do high carbohydrate diets prevent the development or attentuate the manifestations (or both) of syndrome X? A viewpoint strong against. Current Opinion in Lipidology 1997; 8: 23-7.

164 Rassmussen OW, Thomsen C, Hansen KW, Vesterlund M, Winther E, Hermansen K. Effects on blood pressure, glucose, and lipid levels of a high-monounsaturated fat diet compared with a high-carbohydrate diet in NIDDM subjects. Diabetes Care 1993; 16: 1565-71.

165 Krauss RM, Eckel RH, Howard B, et al. AHA dietary guidelines revision 2000: a statement for healthcare professionals from the Nutrition Committee of the American Heart Association. Circulation 2000 2000; 102: 2284-99.

166 Carbohydrates in Human Nutrition. Report of a Joint FAO/WHO Expert Consultation. FAO Food and Nutrition Paper 66. Rome: Food and Agriculture Organization of the United Nations, 1998.

167 Granfeldt Y, Hagander B, Björck I. Metabolic responses to starch in oat and wheat products. On the importance of food structure, incomplete gelatinization or presence of viscous fibre. European Journal of Clinical Nutrition 1995; 49: 189-99.

168 Granfeldt Y, Björck I, Hagander B. On the importance of processing conditions, products thickness and eggs addition, for the glycemic and hormonal responses to pasta-a comparison with white bread made from pasta ingredients. European Journal of Clinical Nutrition 1991; 45: 489.

169 Englyst H, Kingman S, Cummings J. Classification and measurement of nutritionally important starch fractions. European Journal of Clinical Nutrition 1992; 46: 33S-50S.

170 Holm J, Koellreutter B, Wursch P. Influence of sterilization, drying and oat bran enrichment of pasta on glucose and insulin responses in healthy subjects and on the rate and extent of in vitro starch digestion. European Journal of Clinical Nutrition 1992; 46: 629.

171 Jenkins DJ, Wolever TM, Taylor RH, Barker H, Fielden H, Baldwin JM, Bowling AC, Newman HC, Jenkins AL, Goff DV. Glycemic index of foods: a physiological basis for carbohydrate exchange. American Journal of Clinical Nutrition 1981; 34: 362-6.

172 Trowell HC. Dietary fibre, ischaemic heart disease and diabetes mellitus. Proceeding of the Nutrition Society 1973; 32: $151-7$.

173 Trowell HC. Dietary fibre hypothesis of the aetiology of diabetes mellitus. Diabetes 1975; 24: 762-5.

174 Feskens EJ, Loeber JG, Kromhout D. Diet and physical activity as determinants of hyperinsulinaemia: the Zutphen Elderly Study. American Journal of Epidemiology 1994; 140: $350-60$.

175 Tuomilehto J, Lindstrom J, Eriksson JG, Valle TT, Hamalainen $\mathrm{H}$, Ilanne-Parikka P, Keinanen-Kiukaanniemi S, Laakso M, Louheranta A, Rastas M, Salminen V, Uusitupa $\mathrm{M}$ and for the Finnish Diabetes Prevention Study Group. Prevention of type 2 diabetes mellitus by changes in lifestyle among subjects with impaired glucose tolerance. New England Journal of Medicine 2001; 344: 1343-50. 
176 Diet and exercise dramatically delay type 2 diabetes. Press release of the National Institute of Diabetes and Digestive and Kidney Diseases. August 8, Accessed November 29, 2001 at httpp:/www.nih.gov/news/pr/aug2001/ niddk-08.htm.

177 McIntosch M, Miller C. A diet containing food rich in soluble and insoluble fibre improves glycemic control and reduces hyperlipidemia among patients with type 2 diabetes mellitus. Nutrition Reviews 2001; 59: 52-5.

178 Jenkins DJ, Jenkins AL. Dietary fiber and the glycemic response. Proceedings of the Society for Experimental Biology and Medicine 1985; 180: 422-31.

179 Anderson JW. Fiber and health: an overview. American Journal of Gastroenterology 1986; 81: 892-7.

180 Frost G, Wilding J, Beecham J. Dietary advice based on the glycemic index improves dietary profile and metabolic control in type 2 diabetic patients. Diabetic Medicine 1994; 11: 340-67.

181 Brand JC, Colagiuri S, Crossman S, Allen A, Roberts DC, Truswell AS. Low-glycemic index foods improve long-term glycemic control in NIDDM. Diabetes Care 1991; 14: 95-101.

182 Fontvieille AM, Rizkalla SW, Penfornis A, Acosta M, Bornet FR, Slama G. The use of low glycaemic index foods improves metabolic control of diabetic patients over five weeks. Diabetic Medicine 1992; 9: 444-50.

183 Wolever TMS, Jenkins DJA, Vuksan V, Jenkins AL, Buckley GC, Wong GS, Josse RG. Beneficial effect of a low glycemic index diet in type 2 diabetes. Diabetic Medicine 1992; 9 $451-8$.

184 Jenkins DJ, Wolever TM, Kalmusky J, et al. Low-glycemic index diet in hyperlipidemia: use of traditional starchy foods. American Journal of Clinical Nutrition 1987; 45: $66-71$.

185 Brand-Miller JC. The importance of glycemic index in diabetes. American Journal of Clinical Nutrition 1994; 59(Suppl.): $747 \mathrm{~S}-52 \mathrm{~S}$

186 Kushi LH, Meyer KA, Jacobs DR. Cereals, legumes, and chronic disease risk reduction: evidence from epidemiologic studies. American Journal of Clinical Nutrition 1999; 70(Suppl): 451S-8S.

187 Liu S, Stampfer MJ, Hu FB, Giovannucci E, Rimm E, Manson JE, Hennekens CH, Willett WC. Whole-grain consumption and risk of coronary heart disease: results from the Nurses' Health Study. American Journal of Clinical Nutrition 1999; 70: 412-9.

188 Jacobs DR, Meyer KA, Kushi LH, Folsom AR. Whole-grain intake may reduce the risk of ischemic heart disease death in postmenopausal women: the Iowa Women's Health Study. American Journal of Clinical Nutrition 1998; 68 : $248-57$.

189 Department of Health. Dietary Reference Values for Food Energy and Nutrients for the United Kingdom. Report of the Panel on Dietary Reference Values of the Committee on Medical Aspects of Food Policy. London: HMSO, 1991.

190 Sullivan A. Healthy eating: something to chew over? Nursing Standards 2000; 14: 43-6.

191 Hannon-Fletcher M, Hughes C, O'Kane MJ, Moles KW, Barnett CR, Barnett YA, In: Basu TK, Temple NJ and Garg ML eds. Antioxidants in Human Health and Disease. Wallingford, UK: CABI Publishing, 1999, 259-69.

192 Jain SK. Oxidative stress, vitamin E and diabetes. In: Basu TK, Temple NJ, Garg ML, eds. Antioxidants in Human Health and Disease. Wallingford, UK: CABI Publishing, 1999, 249-57.

193 Salonen JT, Nyyssonen K, Tuomainen TP, Maenpaa PH, Korpela H, Kaplan GA, Lynch J, Helmrich SP, Salonen R. Increased risk of non-insulin dependent diabetes mellitus at low plasma vitamin E concentrations: a four year follow up study in men. British Medical Journal 1995; 311: 1124-7.
194 Reunanen A, Knekt P, Aaran RK, Aromaa A. Serum antioxidants and risk of non-insulin dependent diabetes mellitus. European Journal of Clinical Nutrition 1998; 52 89-93.

195 Kao WH, Folsom AR, Nieto FJ, Mo JP, Watson RL, Brancati FL. Serum and dietary magnesium and the risk for type 2 diabetes mellitus: the Atherosclerosis Risk in Communities Study. Archives of Internal Medicine 1999; 159: 2151-9.

196 Schwarz K, Mertz W. Chromium (III) and the glucose tolerance factor. Archives of Biochemistry and Biophysics 1959; 85: 292-5.

197 Lukaski HC. Chromium as a supplement. Annual Review of Nutrition 1999; 19: 279-302.

198 Vincent JB. Quest for the molecular mechanism of chromium action and its relationship to diabetes. Nutrition Reviews 2000; 58(3): 67-72.

199 Anderson RA, Polansky MM, Bryden NA, Canary JJ. Supplemental-chromium effects on glucose, insulin, glucagon, and urinary chromium losses in subjects consuming controlled low-chromium diets. American Journal of Clinical Nutrition 1991; 54: 909-16.

200 Striffler JS, Polansky MM, Anderson RA. Dietary chromium decreases insulin resistance in rats fed a high-fat, mineralimbalanced diet. Metabolism 1998; 47: 396-400.

201 Striffler JS, Law JS, Polansky MM, Bhathena SJ, Anderson RA. Chromium improves insulin response to glucose in rats. Metabolism 1995; 44: 1314-20.

202 Anderson RA, Bryden NA, Polansky MM, Gautschi K. Dietary chromium effects on tissue chromium concentrations and chromium absorption in rats. Journal of Trace Elements in Experimental Medicine 1996; 9: 11-25.

203 Anderson RA, Cheng N, Bryden NA, Polansky MM, Cheng $\mathrm{N}$, Chi J, Feng J. Elevated intakes of supplemental chromium improve glucose and insulin variables in individuals with type 2 diabetes. Diabetes 1997; 46: 1786-91.

204 Stampfer MJ, Colditz GA, Willett WC, Manson JE, Arky RA, Hennekens CH, Speizer FE. A prospective study of moderate alcohol drinking and risk of diabetes in women. American Journal of Epidemiology 1988; 128: 549-58.

205 Rimm EB, Chan J, Stampfer MJ, Colditz GA, Willett WC. Prospective study of cigarette smoking, alcohol use, and the risk of diabetes in men. British Medical Journal 1995; 310: $555-9$.

206 Ajani UA, Hennekens CH, Spelsberg A, Manson JE. Alcohol consumption and risk of type 2 diabetes mellitus among US male physicians. Archives of Internal Medicine 2000; 160 1025-30.

207 Kao WH, Puddey IB, Boland LL, Watson RL, Brancati FL. Alcohol consumption and the risk of type 2 diabetes mellitus: Atherosclerosis Risk in Communities Study. American Journal of Epidemiology 2001; 154: 748-57.

208 O'Sullivan JB. Diabetes mellitus after GDM. Diabetes 1991; 40(Suppl. 2): 131-5.

209 Pettitt DJ, Knowler WC, Baird HR, Bennett PH. Gestational diabetes: infant and maternal complications of pregnancy in relation to third-trimester glucose tolerance in the Pima Indians. Diabetes Care 1980; 3: 458-64.

210 Pettitt DJ, Aleck KA, Baird HR, Carraher MJ, Bennett PH Knowler WC. Congenital susceptibility to NIDDM. Role of intrauterine environment. Diabetes 1988; 37: 622-8.

211 Gautier JF, Wilson C, Weyer C, Mott D, Knowler WC, Cavaghan M, Polonsky KS, Bogardus C, Pratley RE. Low acute insulin secretory responses in adult offspring of people with early onset type 2 diabetes. Diabetes 2001; 50: 1828-33

212 Dabelea D, Hanson RL, Lindsay RS, Pettitt DJ, Imperatore G, Gabir MM, Roumain J, Bennett PH, Knowler WC. Intrauterine exposure to diabetes conveys risks for type 2 
diabetes and obesity: a study of discordant sibships. Diabetes 2000; 49: 2208-11.

213 Hales CN, Barker DJ, Clark PM, Cox LJ, Fall C, Osmond C, Winter PD. Fetal and infant growth and impaired glucose tolerance at age 64. British Medical Journal 1991; 303: 1019-22.

214 Barker DJP, Hales CN, Fall CHD, Osmond C, Phipps K, Clark PMS. Type 2 (non-insulin-dependent) diabetes mellitus, hypertension and hyperlipidaemia (syndrome $\mathrm{X}$ ): relation to reduced fetal growth. Diabetologia 1993; 36: 62-7.

215 Valdez R, Athens MA, Thompson GH, Bradshaw BS, Stern MP. Birthweight and adult health outcomes in a biethnic population in the USA. Diabetologia 1994; 37: 624-31.

216 McCance DR, Pettit DJ, Hanson RL, Jacobsson LTH, Knowler WC, Bennett PH. Birthweight and non-insulin dependent diabetes: 'thrifty genotype', 'thrifty phenotype', or 'surviving small baby genotype'?" British Medical Journal 1994; 308: 942-5.

217 Curhan GC, Willett WC, Rimm EB, Stampfer MJ. Birthweight and adult hypertension and diabetes in US men. Abstract. American Journal of Hypertension 1996; 9: 11A.

218 Lithell HO, McKeigue PM, Berglund L, Mohsen R, Lithell UB, Leon DA. Relation of size at birth to non-insulin dependent diabetes and insulin concentrations in men aged 50-60 years. British Medical Journal 1996; 312: 406-10.

219 Phillips DIW. Insulin resistance as a programmed response to fetal undernutrition. Diabetologia 1996; 39: 1119-22.

220 Barker DJP. Mothers, Babies and Health in Later Life. Edinburgh: Harcourt Brace \& Co. Ltd., 1998.

221 McCance RA, Widdowson EM. The determinants of growth and form. Proceedings of the Royal Society London B Biological Sciences 1974; 185: 1-17.

222 Stern MP, Bartley M, Duggirala R, Bradshaw B. Birth weight and the metabolic syndrome: thrifty phenotype or thrifty genotype?" Diabetes-Metabolism Research and Reviews 2000; 16: 88-93.

223 McCance DR, Pettitt DJ, Hanson RL, Jacobsson LT, Knowler WC, Bennett PH. Birth weight and non-insulin dependent diabetes: thrifty genotype, thrifty phenotype, or surviving small baby genotype?" British Medical Journal 1994; 308: $942-5$.

224 Dabelea D, Pettitt DJ, Hanson RL, Imperatore G, Bennett PH, Knowler WC. Birth weight, type 2 diabetes, and insulin resistance in Pima Indian children and young adults. Diabetes Care 1999; 22: 944-50.

225 Hales CN, Desai M, Ozanne SE. The thrifty phenotype hypothesis: how does it look after 5 years? Diabetic Medicine 1997; 14: 189-95.

226 Lithell HO, McKeigue PM, Berglund L, Mohsen R, Lithell UB, Leon DA. Relation of size at birth to non-insulin dependent diabetes and insulin concentrations in men aged 50-60 years. British Medical Journal 1996; 312: 406-10.

227 Hales CN, Barker DJ. Type 2 (non-insulin-dependent) diabetes mellitus: the thrifty phenotype hypothesis. Diabetologia 1992; 35: 595-601.

228 Ravelli ACJ, van der Meulen JHP, Michels RP, Osmond C, Barker DJ, Hales CN, Bleker OP. Glucose tolerance in adults after prenatal exposure to famine. Lancet 1998; $\mathbf{3 5 1}$ : $173-7$.

229 Barker DJP, Godfrey KM. Fetal nutrition and cardiovascular disease in adult life. In: Wilson $\mathrm{T}$, Temple $\mathrm{N}$, eds. Nutritional Health: Strategies for Prevention. Totowa, NJ: Humana Press, 2001.

230 Fall CHD, Stein CE, Kumaran K, Cox V, Osmond C, Barker DJ, Hales CN. Size at birth, maternal weight, and type 2 diabetes in South India. Diabetic Medicine 1998; 15: 220-7.

231 Mathews F, Yudkin P, Neil A. Influence of maternal nutrition on outcome of pregnancy: prospective cohort study. British Medical Journal 1999; 319: 339-43.
232 Campbell DM, Hall MH, Barker DJP, Cross J, Shiell AW, Godfrey KM. Diet in pregnancy and the offspring's blood pressure 40 years later. British Journal of Obstetrics and Gynaecology 1996; 103: 273-80.

233 Godfrey K, Robinson S, Barker DJP, Osmond C, Cox V. Maternal nutrition in early and late pregnancy in relation to placental and fetal growth. British Medical Journal 1996; 312: $410-4$.

234 Bennett PH. Type 2 diabetes among the Pima Indians of Arizona: an epidemic attributable to environmental change. Nutrition Reviews 1999; 57: S51-4.

235 Pettitt DJ, Forman MR, Hanson RL, Knowler WC, Bennett $\mathrm{PH}$. Breastfeeding and incidence of non-insulindependent diabetes mellitus in Pima Indians. Lancet 1997; 350: 166-8.

236 Young TK, Martens PJ, Taback SP, Sellers EA, Dean HJ, Cheang M, Flett B. Type 2 diabetes mellitus in children: prenatal and early infancy risk factors among native Canadians. Archives of Pediatrics \& Adolescent Medicine 2002; 156: 651-5.

237 Pradhan AD, Manson JE, Rifai N, Buring JE, Ridker PM. C-reactive protein, interleukin 6 , and risk of developing type 2 diabetes mellitus. Journal of the American Medical Association 2001; 286: 327-34.

238 Festa A, D'Agostino R Jr, Mykkanen L, Tracy RP, Zaccaro DJ, Hales CN, Haffner SM. Relative contribution of insulin and its precursors to fibrinogen and PAI- 1 in a large population with different states of glucose tolerance. The Insulin Resistance Atherosclerosis Study (IRAS). Arteriosclerosis Thrombosis and Vascular Biology 1999; 19: 562-8.

239 Pickup JC, Crook MA. Is type II diabetes mellitus a disease of the innate immune system? Diabetologia 1998; 41: 1241-8.

240 Lindsay RS, Krakoff J, Hanson RL, Bennett PH, Knowler WC. Gamma globulin levels predict type 2 diabetes in the Pima Indian population. Diabetes 2001; 50: 1598-603.

241 Lindstedt $G$, Lundberg PA, Lapidus L, Lundgren $H$, Bengtsson C, Bjorntorp P. Low sex hormone-binding globulin concentration as independent risk factor for development of NIDDM: 12-year follow-up of population study of women in Gothenburg, Sweden. Diabetes 1991; 40: $123-8$.

242 Haffner SM, Valdez RA, Morales PA, Hazuda HP, Stern MP. Decreased sex hormone-binding globulin predicts noninsulin-dependent diabetes mellitus in women but not in men. Journal of Clinical Endocrinology \& Metabolism 1993; 77: 56-60.

243 Haffner SM, Karhapää P, Mykkänen L, Laakso M. Insulin resistance, body fat distribution and sex hormones in men. Diabetes 1994; 43: 212-9.

244 Charles MA, Pettitt DJ, McCance DR, Hanson RL, Bennett $\mathrm{PH}$, Knowler WC. Gravidity, obesity, and non-insulindependent diabetes among Pima Indian women. American Journal of Medicine 1994; 97: 250-5.

245 Pan XR, Li GW, Hu YH, et al. Effects of diet and exercise in preventing NIDDM in people with impaired glucose tolerance. The Da Qing IGT and Diabetes Study. Diabetes Care 1997; 20: 537-44.

246 Eriksson K-F, Lindgarde F. Prevention of type 2 (noninsulin-dependent) diabetes mellitus by diabetes mellitus by diet and physical exercise: the 6-Year Malmo Feasibility Study. Diabetologia 1991; 34: 891-8.

247 Uusitupa M, Louheranta A, Lindstrom J, Valle T, Sundvall J, Eriksson J, Tuomilehto J. The Finnish Diabetes Prevention Study. British Journal of Nutrition 2000; 83(Suppl. 1): S137-42.

248 Temple NJ, Nestle M. Population nutrition, health promotion and government policy. In: Wilson $\mathrm{T}$, Temple NJ, eds. Nutritional Health: Strategies for Diseases Prevention. Totowa, NJ: Humana, 2001, 13-29. 